\title{
Miocene UHT granulites from Seram, eastern Indonesia: a geochronological-REE study of zircon, monazite and garnet
}

\author{
J. M. POWNALL ${ }^{1,2 *}$, R. A. ARMSTRONG ${ }^{1}$, I. S. WILLIAMS ${ }^{1}$, \\ M. F. THIRLWALL ${ }^{3}$, C. J. MANNING ${ }^{3} \&$ R. HALL ${ }^{2}$ \\ ${ }^{1}$ Research School of Earth Sciences, Australian National University, Canberra, \\ ACT 2601, Australia \\ ${ }^{2}$ SE Asia Research Group, Department of Earth Sciences, Royal Holloway \\ University of London, Egham TW20 OEX, UK \\ ${ }^{3}$ Department of Earth Sciences, Royal Holloway University of London, \\ Egham TW20 OEX, UK \\ D.M.P., 0000-0002-6013-3193; R.A.A., 0000-0002-3062-0679; \\ I.S.W., 0000-0003-4465-6493; R.H., 0000-0003-1693-6914 \\ *Correspondence: jonathan.pownall@anu.edu.au
}

\begin{abstract}
The island of Seram, eastern Indonesia, incorporates Miocene ultrahigh-temperature (UHT; $>900^{\circ} \mathrm{C}$ ) garnet-sillimanite granulites that formed by extensional exhumation of hot mantle rocks behind the rolling-back Banda Arc. UHT metamorphic conditions are supported by new Zr-in-rutile thermometry results and the Miocene age of the UHT event is confirmed by closely-matched heavy rare earth element (HREE) abundances between garnet and $c$. $16 \mathrm{Ma}$ zircon. Monazites also record identical U-Pb ages, within uncertainty. However, these geochronometers do not date peak UHT metamorphism; instead, they date retrograde, garnetconsuming ( $\mathrm{Zr}$ - and rare earth element (REE)-liberating) reactions that produced the granulites' post-peak cordierite + spinel reaction microstructures. Zircons shielded within garnet did not crystallize $c$. $16 \mathrm{Ma}$ rims and so were unaffected by the entire UHT event. Miocene UHT metamorphism overprinted a Late TriassicEarly Jurassic upper-amphibolite facies event that grew garnet cores and 216-173 Ma zircon. In the Miocene, these garnet cores were overgrown by peritectic garnet rims during UHT metamorphism, with some rutiles recording c. $900^{\circ} \mathrm{C} \mathrm{Zr-in-rutile} \mathrm{temperatures.} \mathrm{Garnet} \mathrm{Lu-Hf} \mathrm{ages} \mathrm{of} 138 \mathrm{Ma}$ - produced by core-rim mixing - demonstrate that a component of $\mathrm{Hf}^{4+}$ produced since $c$. $200 \mathrm{Ma}$ was retained through the $c$. 16 Ma UHT event. Accordingly, UHT conditions must have been very short-lived and exhumation of the granulite complex very rapid.
\end{abstract}

Supplementary material: Zircon REE data (SHRIMP) and garnet REE data (LA-ICP-MS) are available at https://doi.org/10.6084/m9.figshare.c.4070324

Ultrahigh-temperature (UHT; $>900^{\circ} \mathrm{C}$ ) granulites were produced in eastern Indonesia by extension following the Miocene collision of Australia with SE Asia (Pownall et al. 2014). These rocks, exposed on the island of Seram (Figs $1 \& 2$ ), record the youngest of only $c$. 60 known instances when the geothermal gradient was elevated locally beyond the UHT threshold of $700^{\circ} \mathrm{C} \mathrm{GPa}^{-1}$ (Brown 2006, 2014; Harley 2008, 2016; Kelsey 2008; Kelsey \& Hand 2015). Importantly, the Seram UHT granulites occur within the same tectonic system that generated the UHT conditions, thereby enabling detailed study of their formation mechanism without complications introduced by multiple overprinting deformational and metamorphic episodes. This is in contrast to the vast majority of UHT terranes that reside in Proterozoic cratons and whose tectonic drivers remain far more elusive (Kelsey \& Hand 2015). As such, these young Indonesian granulites offer a unique opportunity to investigate (1) how UHT conditions may be generated by the modern Earth and (2) potential pressure-temperature $(P-T)$ paths and metamorphic rates experienced by high-grade metamorphic rocks in modern arc settings.

The Seram UHT granulites comprise part of the Kobipoto migmatite complex (Pownall 2015; Pownall et al. 2017a) - a suite of garnet- and cordieritebearing diatexites hosting garnet-sillimanitecordierite-spinel residua (following migmatite terminology of Sawyer 2008). The residual assemblage features spinel + quartz inclusions within garnet and quartz-absent sapphirine + corundum + spinel symplectite within cordierite (Fig. 3). Phase equilibria modelling of the $\mathrm{Al}-\mathrm{Fe}-$ rich granulite 


\section{J. M. POWNALL ET AL}

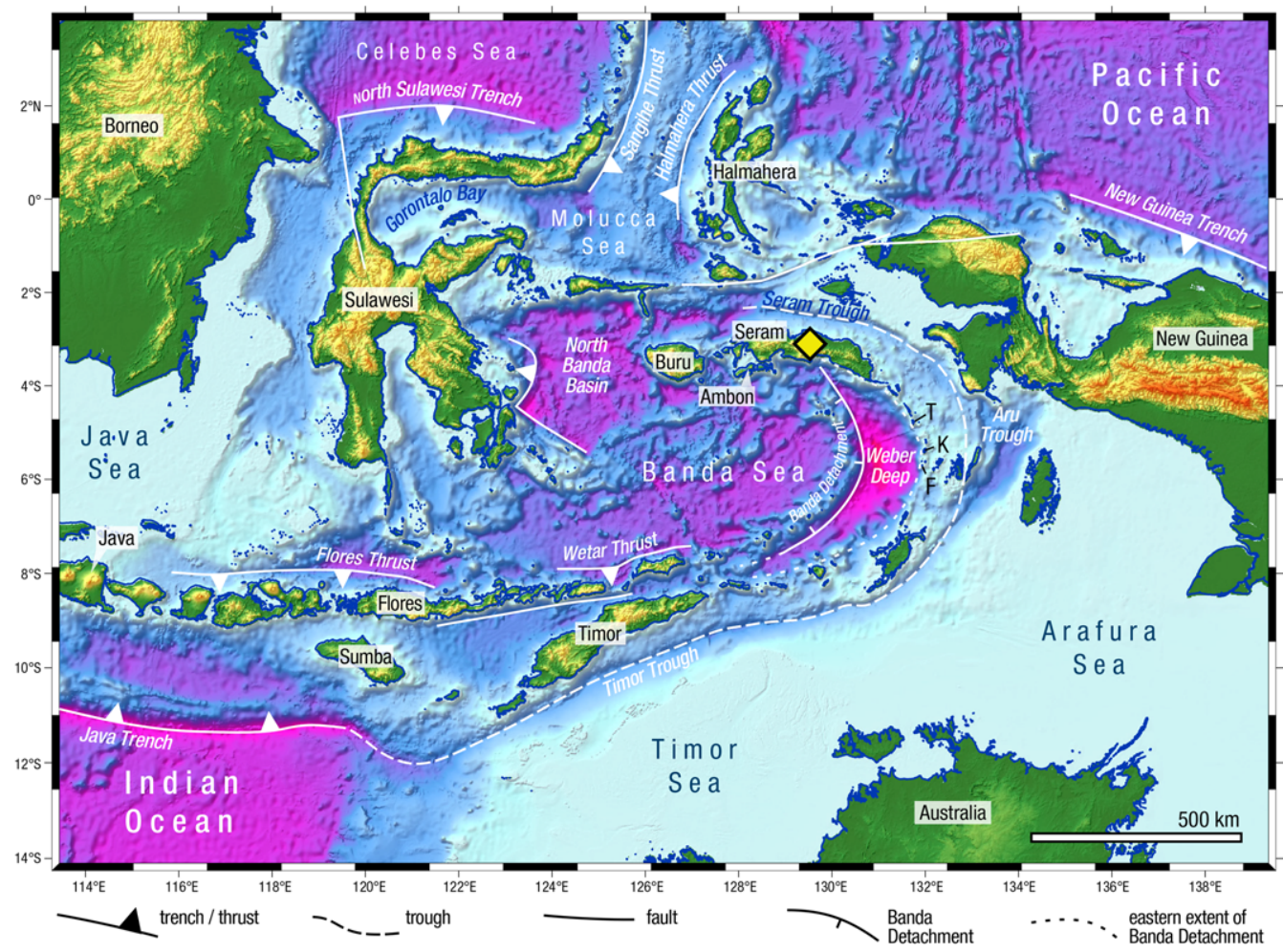

Fig. 1. Tectonic map of Eastern Indonesia. The island of Seram is located in the northern limb of the Banda Arc. Tectonic features are from Hall (2012), with the location of the Banda Detachment from Pownall et al. (2016). Islands to the north of the Banda Sea once comprised the Sula Spur (Klompé 1954) - a continental promontory extending from NW Australia (Fig. 19d) that fragmented upon collision with western Sulawesi (SE Asia). Base-map elevation data are from Ryan et al. (2009). The yellow diamond indicates the sampling locality for the Kobipoto Complex granulites involved in this study. T, Tioor; K, Kur; F, Fadol.

melanosome (Pownall 2015) indicated peak $P-T$ conditions of $925^{\circ} \mathrm{C}$ and $9 \mathrm{kbar}$ for the interpreted peak model assemblage garnet + sillimanite + spinel + ilmenite + plagioclase + silicate melt. A clockwise $P-T$ path through these peak conditions (Fig. 4) was interpreted to descend steeply downpressure from garnet-present to cordierite-present fields to account for the most dominant discontinuous retrograde reaction interpreted to have affected the assemblage: garnet + sillimanite $\rightarrow$ cordierite + spinel \pm quartz, at 7-6 kbar (Fig. 4), which developed the granulites' characteristic ordered reaction microstructures (Fig. 3). But when, and how rapidly, did metamorphism occur, and what was the tectonic driver for the metamorphism and subsequent exhumation?

Two critical observations from field mapping (Pownall et al. 2013, 2016) explain how UHT conditions on Seram were attained. First, the granulites and associated diatexites always coexist with voluminous lherzolites (Pownall et al. 2017a) and, secondly, this granulite-lherzolite complex has been exhumed by considerable extension beneath low-angle detachment faults, still at high enough temperatures to have generated partial melting in the hanging wall (Pownall et al. 2017b). Initially interpreted to comprise part of an ophiolite (e.g. Linthout et al. 1996), these lherzolites have an exhumed subcontinental lithospheric mantle origin and their rapid juxtaposition against shallower crustal rocks (at $35 \mathrm{~km}$ depth, to correspond with peak metamorphic pressure) was sufficient to have elevated crustal temperatures into the UHT regime (Fig. 4; Pownall et al. 2017a).

The island of Seram is located in the northern limb of the Banda Arc (Fig. 1), beneath which an inwardly concave slab of Jurassic oceanic lithosphere has been subducted (Spakman \& Hall 2010; Hall 2011, 2017, 2018; Pownall et al. 2016). The extremely curved geometry of the Banda Arc and its underlying slab was achieved by subduction rollback, whereupon collapse of the down-going slab drove southeastward migration of the subduction 


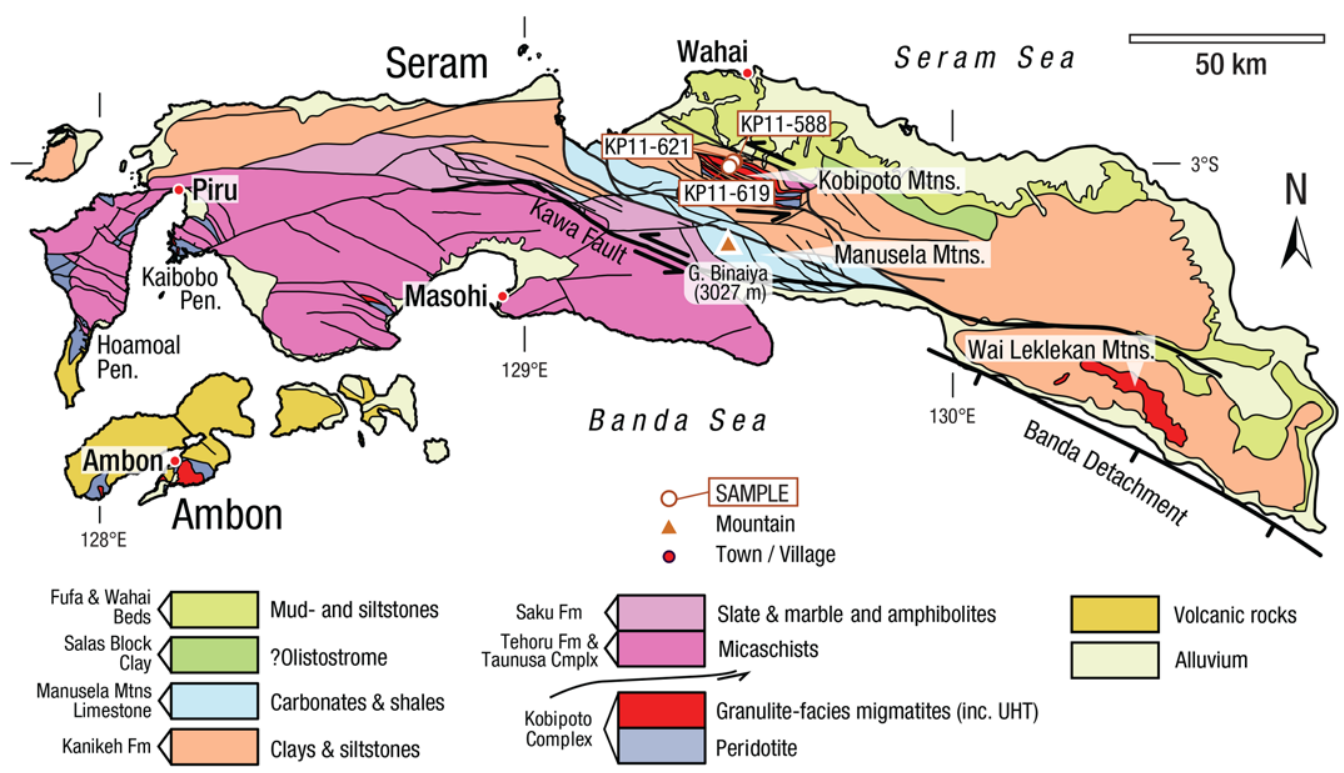

Fig. 2. Geological sketch map of Seram and Ambon, after Valk (1945), Germeraad (1946), van der Sluis (1950), Tjokrosapoetro et al. (1993a, b), Gafoer et al. (1993), and Pownall et al. (2013, 2014, 2016). Samples KP11-588 and KP11-619 are located in the Kobipoto Mountains. Pen., Peninsular; Mtns, Mountains.

hinge-line and adjacent trench. As depicted by regional plate reconstructions (e.g. Hall 2012), Banda slab rollback drove oceanic spreading within the trailing Banda Sea as well as continental rifting and hot hyperextension within the fringes of the Australian continental margin (the 'Sula Spur', of which Seram is derived). A compilation of ${ }^{40} \mathrm{Ar} /{ }^{39} \mathrm{Ar}$ ages dating shear-zone movements on Seram (Pownall et al. 2017b) and oceanic spreading histories of the Banda Sea basins (Hinschberger et al. 2000, 2001) demonstrate that Banda Arc rollback commenced around $16 \mathrm{Ma}$ before propagating southeastwards towards Australia. The latest phase of this rollbackdriven extension from $2 \mathrm{Ma}$ 'rolled open' the $7 \mathrm{~km}$ Weber Deep basin in the easternmost Banda Sea, further exhuming lherzolites across a chain of small islands bordering the abyss (Pownall et al. 2016).

Zircon U-Pb dating of the Seram UHT granulite residuum and associated diatexites (Pownall et al. 2014, 2017a) revealed 3 separate age populations (Fig. 5; Table 1): (1) ages obtained for detrital cores between $3.4 \mathrm{Ga}$ and $216 \mathrm{Ma}$; (2) a broad spread of ages obtained from core-truncating overgrowths between 215 and $173 \mathrm{Ma}$; and (3) a population of $c .16 \mathrm{Ma}$ ages obtained from a second zircon overgrowth (although some ages from this third group are as old as $25 \mathrm{Ma}$ ). Furthermore, ${ }^{40} \mathrm{Ar} /{ }^{39} \mathrm{Ar}$ ages obtained for biotite are within uncertainty of the respective zircon $\mathrm{U}-\mathrm{Pb}$ ages for the same samples, implying exceptionally rapid cooling rates (Pownall et al. 2017b). The close correlation between these latest $c$. $16 \mathrm{Ma}$ zircon $\mathrm{U}-\mathrm{Pb}$ ages with the inferred timing of Banda rollback initiation at $c .16 \mathrm{Ma}$, in light of the tectonic interpretation borne from field observations that UHT conditions were achieved by extreme lithospheric extension, led us to conclude previously that UHT metamorphism occurred at $16 \mathrm{Ma}$ synchronous with the initial phase of extension behind the rapidly rollingback Banda slab (Pownall et al. 2014, 2017a; Pownall 2015). But how robust is this inference for the timing of the UHT event? For instance, how certain are we that UHT metamorphism did not instead occur within the 216-170 Ma window recorded by the oldest zircon overgrowth event? Could we further test our hypotheses using additional geochronometers and, if so, could we integrate the results of different dating techniques with trace element systematics operating during the rocks' metamorphism and melting? These questions provided the motivation behind this current study.

Here, we present new monazite $\mathrm{U}-\mathrm{Pb}$, garnet $\mathrm{Lu}-$ $\mathrm{Hf}$ and garnet $\mathrm{Sm}-\mathrm{Nd}$ data, accompanied by rare earth element (REE) analyses of zircon and garnet plus new Ti-in-zircon and Zr-in-rutile thermometry results. These new data indeed substantiate previous findings that UHT metamorphism on Seram occurred at $c .16 \mathrm{Ma}$ and provide further quantification of the granulite complex's rapid metamorphism and exhumation history. 


\section{J. M. POWNALL ET AL.}
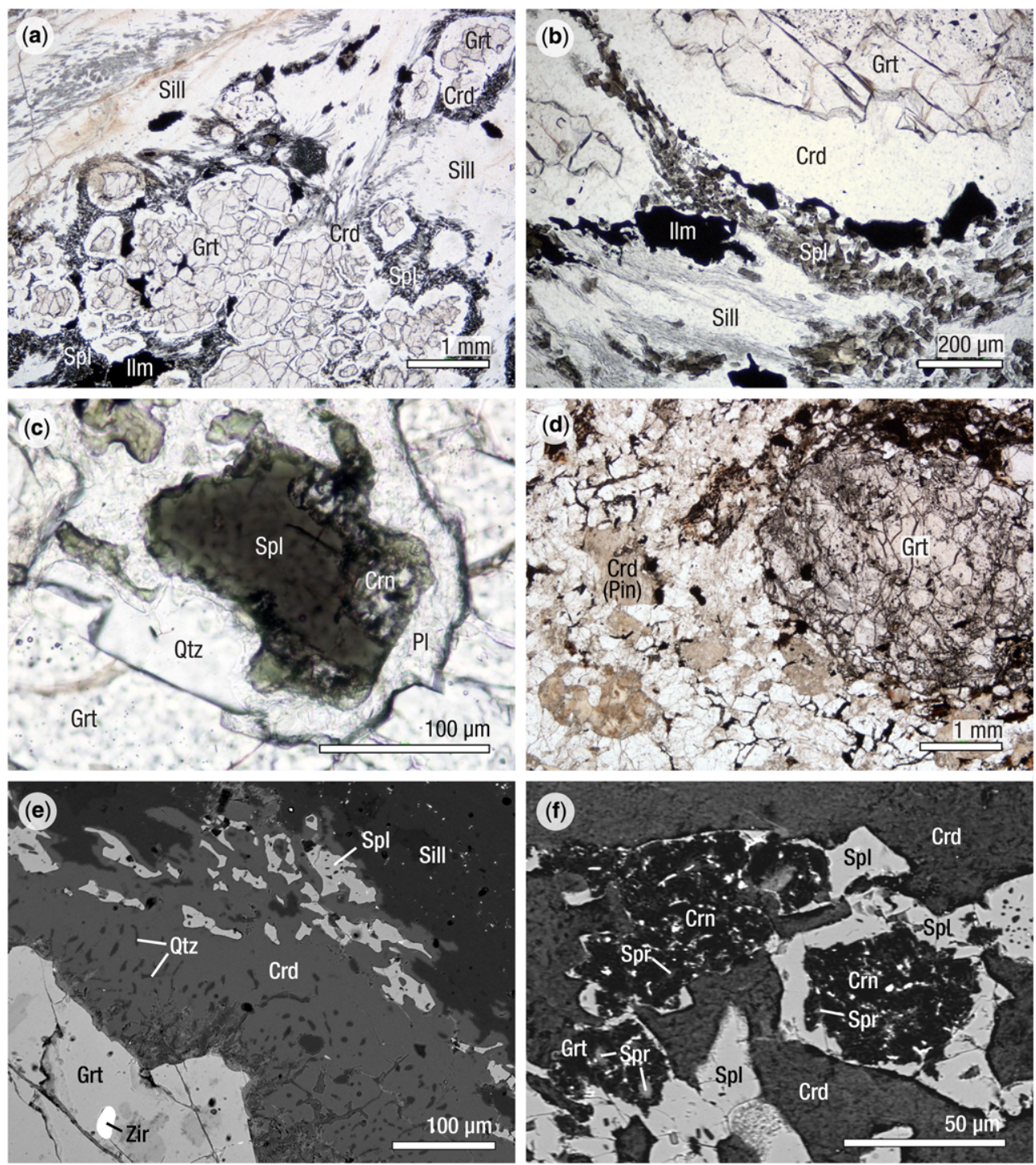

Fig. 3. Thin section photomicrographs (PPL) and back-scattered electron (BSE) images of the Kobipoto Complex granulites. Mineral abbreviations are after Kretz (1983). (a) Sample KP11-588: Voluminous garnet separated from abundant sillimanite by order reaction microstructures of cordierite + spinel + ilmenite. (b) Sample KP11-588: Cordierite corona surrounding garnet, and symplectic spinel and ilmenite adjacent to sillimanite, were produced during retrograde reactions during rapid decompression from peak conditions (see also Pownall 2015). (c) Sample KP11-588: Inclusions of spinel + quartz + corundum within garnet - an assemblage indicative of UHT metamorphism. (d) Sample KP11-619: Large (4 mm diameter) garnet within leucosome comprising pinitized cordierite (pin), plagioclase, quartz and biotite. (e) Sample KP11-588: BSE image of ordered reaction microstructures between garnet and sillimanite. Cordierite corona features vermicular blobs of quartz adjacent to garnet and symplectic spinel grains adjacent to sillimanite. Note the zircon inclusion in garnet. (f) Sample KP11-619: BSE image of symplectic spinel within cordierite, hosting corundum and tiny blebs of sapphirine (see Pownall 2015).

\section{Tectonic and metamorphic context}

Lower-crustal-upper-mantle rocks that comprise the Kobipoto Complex (Pownall 2015) are exposed across Seram (specifically western Seram, the Kobipoto Mountains of central Seram and the Wai Leklekan Mountains of eastern Seram) and within the chain of small islands of Kasiui, Tioor, Kur and 


\section{MIOCENE UHT GRANULITES FROM SERAM}

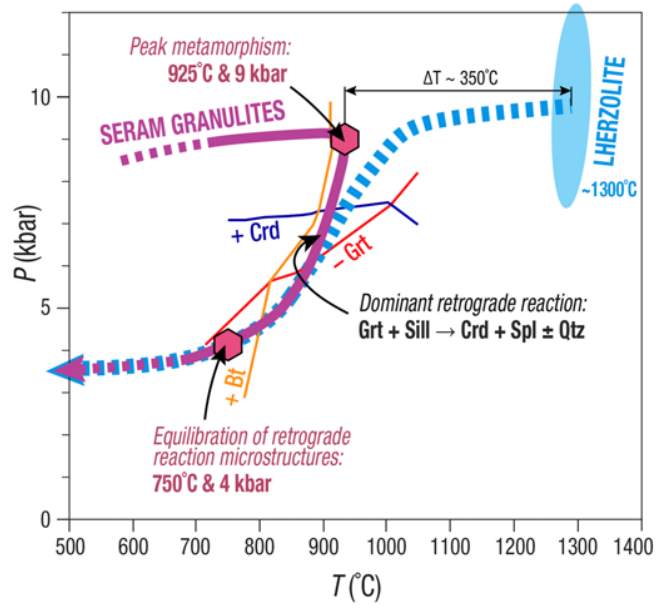

Fig. 4. Summary of $P-T$ data for the Kobipoto Complex granulites and lherzolites, modified after Pownall et al. (2017a) and Pownall (2015). The purple arrow shows a clockwise $P-T$ path for UHT granulite sample KP11-588, passing though peak conditions of $925 \pm 50^{\circ} \mathrm{C}$ at $9 \pm 1 \mathrm{kbar}$. Reaction lines for garnet (Grt), cordierite (Crd), biotite (Bt) and silicate melt (Liq) are taken from a $P-T$ pseudosection calculated specifically for the melanosome using THERMOCALC in the $\mathrm{Na}_{2} \mathrm{O}-\mathrm{CaO}-\mathrm{K}_{2} \mathrm{O}-\mathrm{FeO}-\mathrm{MgO}-\mathrm{Al}_{2} \mathrm{O}_{3}-\mathrm{SiO}_{2}-\mathrm{H}_{2} \mathrm{O}-$ $\mathrm{TiO}_{2}-\mathrm{Fe}_{2} \mathrm{O}_{3}$ (NCKFMASHTO) chemical system. Post-peak equilibration conditions of $754 \pm 116^{\circ} \mathrm{C}$ and $4 \pm 1 \mathrm{kbar}$ are based on a THERMOCALC 'AvePT' calculation for the cordierite- and spinel-dominated reaction microstructures, using the garnet rim composition (Pownall 2015). The blue arrow shows the $P-T$ evolution of the adjacent lherzolites, which juxtaposed against the granulites provided the heat for UHT metamorphism (Pownall et al. 2017a).

Fadol curving round to the easternmost part of the arc (Valk 1945; Germeraad 1946; van der Sluis 1950; Hamilton 1979; Bowin et al. 1980; Charlton et al. 1991; Honthaas et al. 1997; Pownall et al. 2016). No ultramafic rocks or UHT granulites were found by the authors on Buru (Fig. 1), although it is possible that they are present in the shallow subsurface (Linthout et al. 1989).

Most of the metamorphic rocks on Seram (Fig. 2) are chlorite- to kyanite-grade metapelites and intercalated mafic amphibolites belonging to the Tehoru Formation (Tjokrosapoetro \& Budhitrisna 1982), which correlates with the Wahlua Complex on Buru (Linthout et al. 1989). The Tehoru Formation was deposited in the Late Triassic to Early Jurassic (Pownall et al. 2017a), metamorphosed at up to upper amphibolite facies at $c .17 \mathrm{Ma}$ and then subjected to localized deformational events until 3.3 Ma by the operation of major strike-slip fault systems accommodating Banda slab rollback (Pownall et al. 2017b).
Migmatites featuring garnet-sillimanite granulite and lherzolites intruded by the migmatites, together comprise the Kobipoto Complex (Pownall 2015; Pownall et al. 2017a). In western Seram (the Kaibobo and Hoamoal peninsulas; Fig. 2), Kobipoto Complex rocks occur beneath low-angle detachment

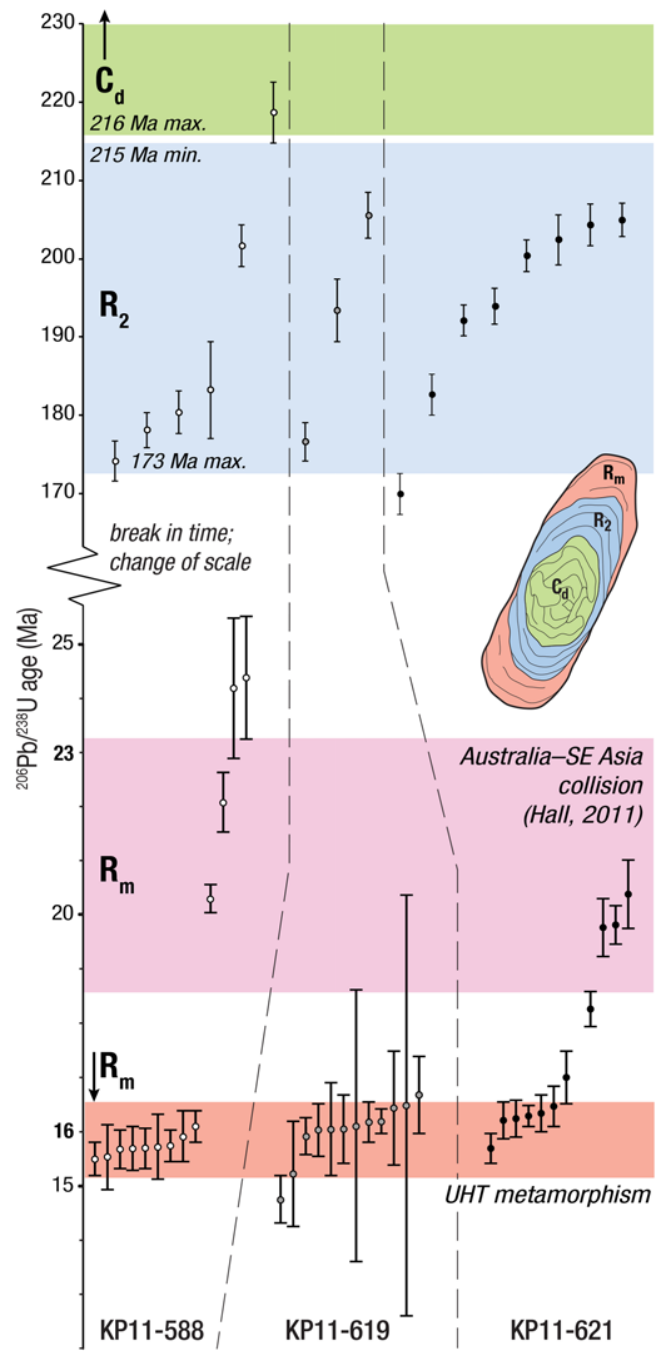

Fig. 5. Summary of $\mathrm{U}-\mathrm{Pb}$ zircon ages obtained for the Kobipoto Complex granulites (after Pownall et al. $2017 a$ ). Note the cluster of $\mathrm{R}_{\mathrm{m}}$ zircon ages at $c .16 \mathrm{Ma}$, the occurrence of some $\mathrm{R}_{\mathrm{m}}$ ages at $c .23 \mathrm{Ma}$ (correlating with the initial collision of Australia with SE Asia; Hall 2011 ), and the broad spread of $R_{2}$ zircon ages between 215 and $173 \mathrm{Ma}$. We do not imply that $\mathrm{R}_{\mathrm{m}}$ zircon rim populations at $c$. $16 \mathrm{Ma}$ and 23-19 Ma were formed by the same process, only that they have identical textural relationships. The 'cartoon' zircon is lifted from Figure $8 \mathrm{~b}$ 
Table 1. Previous geochronology of the Kobipoto Complex migmatites, eastern Indonesia

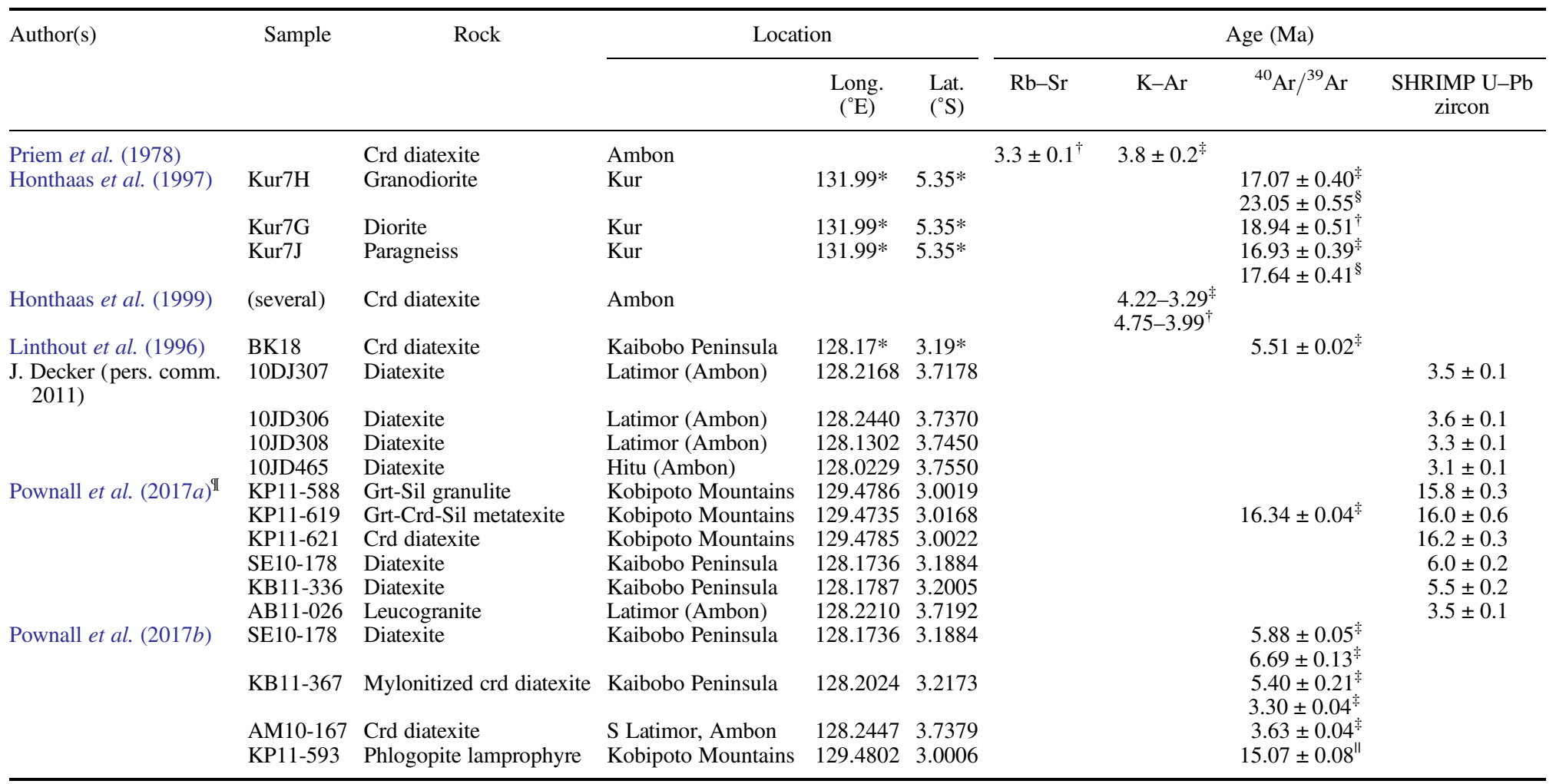

*Locations estimated from maps in Honthaas et al. (1997, fig. 1c) and Linthout et al. (1996, fig. 2), respectively.

Age obtained from a whole rock powder.

${ }^{*}$ Age obtained for biotite (pairs of ages sometimes interpreted for the same sample relate to different Ar reservoirs; see Pownall et al. 2017b).

${ }^{\S}$ Age obtained for K-feldspar.

"Age obtained for phlogopite from a lamprophyric dyke intruded through Kobipoto Complex lherzolites.

${ }^{\pi}$ Ages for KP11-588, KP11-619, and KP11-621 reported initially by Pownall et al. (2014). 


\section{MIOCENE UHT GRANULITES FROM SERAM}

faults, immediately above which are 500 m-thick high-temperature shear zones characterized by sillimanite-defined shear banding and localized partial melting (Pownall et al. 2013, 2017b). We interpret these high- $T$ mylonites (which comprise the Taunusa Complex) to have formed in response to high-temperature exhumation of hot Kobipoto Complex lherzolites and migmatites beneath the detachment (Pownall et al. 2013, 2017a, b). As outlined by Pownall et al. (2013, 2014, 2017a), we therefore consider that the lherzolites must have been exhumed from the subcontinental mantle and so were never part of an ophiolite.

In the Kobipoto Mountains, central Seram (Fig. 2) - the sampling location of granulites investigated in this paper - migmatites and lherzolites have been exhumed within a left-lateral positive flower structure (Pownall \& Hall 2014). This structure is a part of the larger $120-300^{\circ}$-trending Kawa Fault Zone that bisects Seram (Pownall et al. 2013), which itself is a member of the larger SeramKumawa Shear Zone (Hall et al. 2017). This shear zone system accommodated the differences in motion between the southeastward-rolling Banda trench (Spakman \& Hall 2010) and the adjacent Sula Spur promontory of the Australian continental margin.

\section{The Kobipoto Complex granulites}

The Kobipoto Complex is exposed in western Seram, in the Wai Leklekan Mountains of eastern Seram, and on Ambon (Fig. 2). Kobipoto Complex migmatites comprise leucosome-rich diatexites peppered with small schlieren of sillimanite + spinel and contain abundant cordierite and garnet phenocrysts (Priem et al. 1978; Pownall 2015; Pownall et al. 2017a). These diatexites, along with lherzolites with which they share direct contacts, were exhumed beneath detachment faults in western Seram at 5.8 5.6 Ma and on Ambon at 3.5-3.3 Ma (Pownall et al. 2017a, b).

In the Kobipoto Mountains of central Seram, the migmatites contain a higher proportion of residual granulite and stromatic metatexites are therefore more common. Scarce occurrences of highly residual garnet-sillimanite granulite (Fig. 3), described in detail by Pownall (2015), are also present. As mentioned previously, these granulites contain garnet-hosted composite inclusions of spinel + quartz ( \pm ilmenite \pm sillimanite) (Fig. 3c) and post-peak quartz-absent symplectites of sapphirine + corundum + spinel within cordierite that formed during a near-isothermal decompression stage of a clockwise $P-T$ path (Fig. 4; Pownall et al. 2014; Pownall 2015). A THERMOCALC $P-T$ pseudosection (Powell \& Holland 1988) for the residual assemblage indicated peak metamorphic conditions of $925 \pm 50^{\circ} \mathrm{C}$ at $9 \pm 1 \mathrm{kbar}$ (Pownall 2015).
Through the post-peak discontinuous reaction garnet + sillimanite $\rightarrow$ cordierite + spinel \pm quartz $($ Hensen \& Green 1971), the Seram granulites developed prominent reaction microstructures featuring coronae of cordierite containing spinel + corundum \pm sapphirine \pm sillimanite symplectites (Fig. 3a, b, e and f), which formed at $754 \pm 116^{\circ} \mathrm{C}$ and $4 \pm 1 \mathrm{kbar}$ (Pownall 2015).

\section{Sample petrography}

The samples analysed as part of this study KP11-588 and KP11-619 - were both collected from the Wai Tuh river gorge in the Kobipoto Mountains at $\left[129.479^{\circ} \mathrm{E}, 3.002^{\circ} \mathrm{S}\right]$ and $\left[129.474^{\circ} \mathrm{E}\right.$, $3.017^{\circ} \mathrm{S}$ ], respectively (Fig. 2).

- Garnet-sillimanite granulite KP11-588 (Fig. 3ac) is a highly residual granulite, containing abundant garnet (c. $25 \mathrm{vol} \%$ ) and prismatic sillimanite (c. $20 \mathrm{vol} \%$ ) separated by ordered reaction microstructures comprising cordierite coronae and cordierite + spinel \pm ilmenite \pm corundum \pm sapphirine symplectites (Fig. 3a, b and e). Plagioclase and quartz also feature within some cordierite coronae as narrow, vermicular intergrowths (Fig. 3e). Ilmenite is fairly abundant (5$10 \mathrm{vol} \%$ ) and occurs as inclusions within garnet and also as coarse grains bordering spinel (Fig. $3 b)$. Coexisting spinel + quartz ( \pm corundum) occurs as small inclusions within garnet (Fig. 3c). These composite inclusions are interpreted to have formed by localized reactions consuming former sillimanite and ilmenite inclusions with garnet (Pownall 2015).

- Garnet-cordierite-sillimanite metatexite KP11-619 (Fig. 3d, f) features abundant melanosome comprising cordierite + biotite + garnet + sillimanite . Garnets are large (sometimes $>5 \mathrm{~mm}$ ) and cordierite is typically pinitized. Some of the fresher cordierite contains sprays of sillimanite needles and biotite. Compared to sample KP11-588, this rock contains a far higher proportion of leucosome (c. $60 \mathrm{vol} \%$ ).

\section{Textural locations of zircon, monazite and rutile}

Zircon and monazite both occur throughout the rock (1) as inclusions within garnet, (2) within post-peak reactions microstructures in which garnet has been replaced by cordierite + spinel, (3) within sillimanite and (4) within the leucosome (Fig. 6a-d). Both zircon and monazite grains are larger and more abundant within the cordierite coronae and leucosome than as inclusions within garnet. Rutile occurs both as inclusions within garnet and within the leucosome, adjacent to garnet (Fig. 6e, f). 

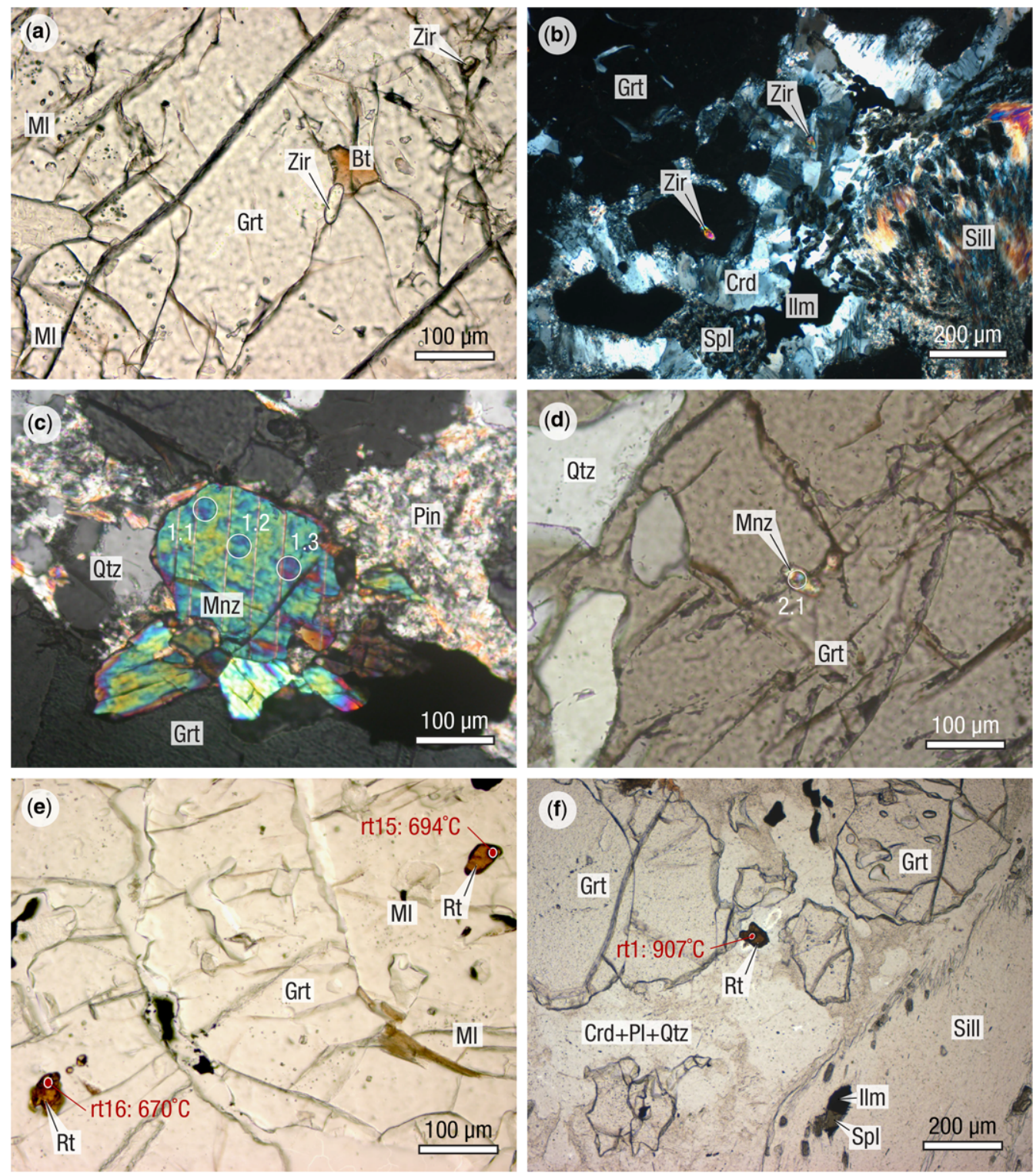

Fig. 6. Textural settings of zircon, monazite and rutile in granulite KP11-588. Mineral abbreviations are after Kretz (1983). (a) Zircon inclusion within garnet that also contains small melt inclusions (MI) and a biotite inclusion (PPL image). See Figure 9b for CL image of this grain. (b) Zircon grains present within cordierite corona and included within garnet (XPL image). (c, d) Monazite grains dated in situ as part of this study. The ablation pit numbers correspond to those in Table 2 and Figure 10. (e, f) Rutile grains analysed in situ for Zr-in-rutile thermometry. Analytical spots correspond to those in Table 4. Rutile grains in the leucosome record UHT conditions $\left(>900^{\circ} \mathrm{C}\right)$, whereas those included in garnet have significantly lower $\mathrm{Zr}$ concentrations that yield lower temperatures (c. $\left.600-750^{\circ} \mathrm{C}\right)$.

\section{Melt inclusions within garnet}

We report melt inclusions (MIs) within some garnets of sample KP11-588, identified by optical microscopy
(Fig. 7). The MIs, which are $<10 \mu \mathrm{m}$ diameter, are characterized by their square cross-sections, composite interiors and distinctive rims (Fig. 7b). The mineralogy of individual domains is unfortunately 


\section{MIOCENE UHT GRANULITES FROM SERAM}
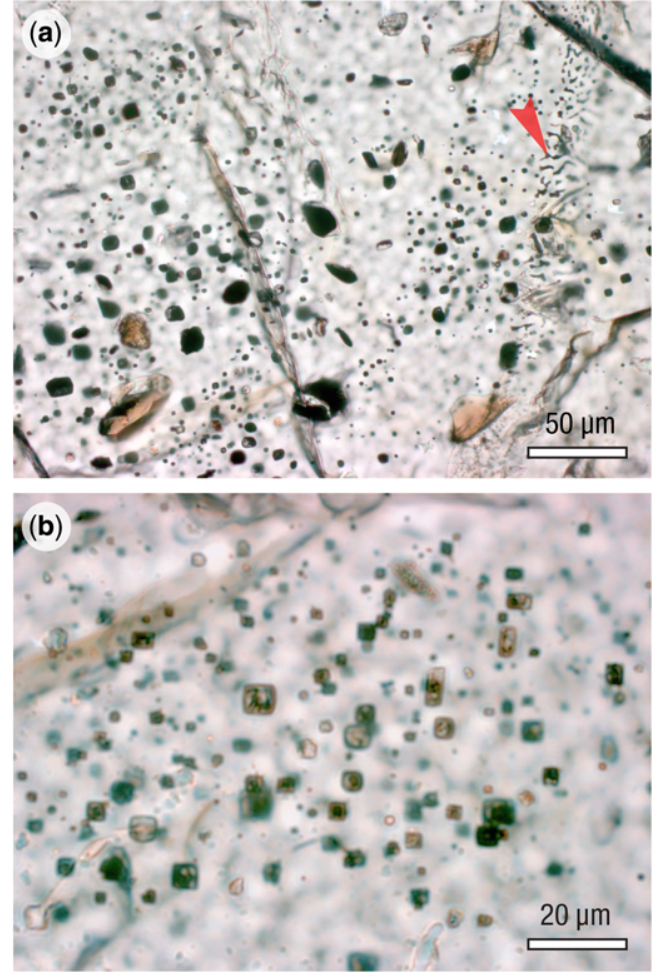

Fig. 7. (a, b) Melt inclusions (MI) within garnet of sample KP11-588 (photomicrographs, PPL). Note the occurrence of both primary inclusions (square in thin section), and secondary melt inclusions located along planar defects, as shown by the red arrow in part (a).

too small to determine optically, although the overall appearance of the MIs do seem to resemble polycrystalline nanogranitoids (Cesare et al. 2015). The MIs are clustered in large groups that are distributed sporadically throughout some garnets (Fig. 7a). Many garnets do not host MIs and only a small minority host MIs larger than $5 \mu \mathrm{m}$. In addition to these primary MIs, smaller and blebbier MIs occur along planar fractures through the garnet (red arrow in Fig. 7a), which we interpret as secondary features.

We interpret the widespread occurrence of primary MIs as further evidence that (most) garnet must have grown in the presence of melt as a solid peritectic product of melt-producing reactions. This conclusion is consistent with the result from phase equilibria modelling (Pownall 2015) that both peak metamorphism and high-temperature retrogression occurred above the solidus (Fig. 4). As shown in Figure 6a, zircon is present in garnets that also host MIs, suggesting that some zircons and other accessory minerals may have been entrapped in garnet in the presence of melt.

\section{SHRIMP U-Pb zircon geochronology}

Zircon $\mathrm{U}-\mathrm{Pb}$ ages for Kobipoto Complex granulites and diatexites were measured previously by Pownall et al. (2014, 2017a) using sensitive high-resolution ion microprobes SHRIMP-II and SHRIMP-RG (reverse geometry) at the Research School of Earth Sciences (RSES), Australian National University (ANU), Canberra (see Pownall et al. 2017a for detailed analytical and data reduction methods). Cathodoluminescence (CL) images (Fig. 8) were acquired for all zircons mounted in epoxy for U$\mathrm{Pb}$ dating at the RSES using a CL hyperspectral imaging system paired with a Cameca SX-100 electron microprobe. In order to provide petrographic context, CL images were also acquired at the RSES for zircons in situ within a thin section of sample KP11-588 (Fig. 9) using a CL detector paired with a JEOL 6610A SEM $(15 \mathrm{kV}, 1 \mu \mathrm{m}$-diameter beam).

Zircons from the Kobipoto Complex show complex internal structures arising from multiple growth and dissolution events. These relationships are illustrated by the CL images and cartoon zircons presented in Figure 8. Typically, a zircon from the residual granulites (e.g. sample KP11-588) will feature a detrital core around which are two distinct overgrowths, identified from CL images due to different CL responses and their cross-cutting relationships. Following Pownall et al. (2017a), we have used the following scheme to describe different parts of the zircon grains:

- $\mathrm{C}_{\mathrm{d}}$ - detrital zircon cores;

- $\mathrm{C}_{\mathrm{m}}$ - magmatic or metamorphic cores (sample-dependent);

- $\mathrm{R}_{\mathrm{m}}$ - magmatic or metamorphic zircon rims (sample-dependent);

- $\mathrm{R}_{2}$ - an inner CL-bright rim between outer $\mathrm{R}_{\mathrm{m}}$ rims and $\mathrm{C}_{\mathrm{d}}$ cores (or sometimes as the only rim around $\mathrm{C}_{\mathrm{d}}$ cores);

- $\mathrm{R}_{\mathrm{o}}$ - very thin CL-bright overgrowths (that were too small to analyse).

The U-Pb zircon geochronology results of Pownall et al. (2017a) are detailed in Table 1 and Figure 5. In summary, detrital cores $\left(\mathrm{C}_{\mathrm{d}}\right)$ are aged between $3.4 \mathrm{Ga}$ and $216 \mathrm{Ma} ; \mathrm{R}_{2}$ overgrowths yielded ages between 215 and $173 \mathrm{Ma}$; and younger $R_{m}$ rims are $c .16 \mathrm{Ma}$.

An important new finding, revealed by the in-situ CL imaging, is that zircons included within garnet do not have $c .16 \mathrm{Ma}_{\mathrm{m}}$ rims (Fig. 9b-e). These younger rims are present only on zircons located in the post-peak reaction microstructures and the leucosome (Fig. 9a). Zircons in all textural settings feature c. $200 \mathrm{Ma}_{2}$ zones around detrital $\mathrm{C}_{\mathrm{d}}$ cores. These relationships are consistent across a total of 26 zircon grains imaged in situ using CL. 


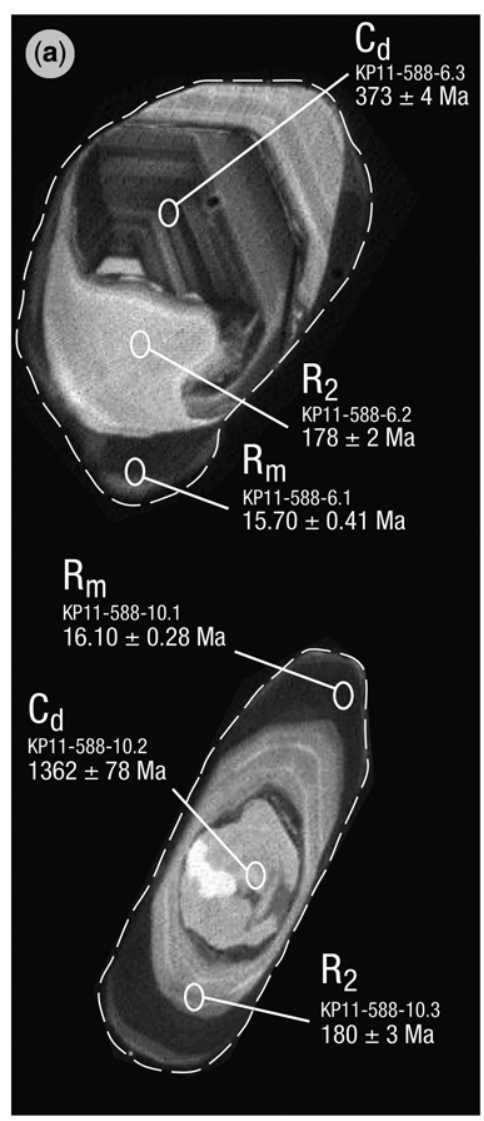

(b)
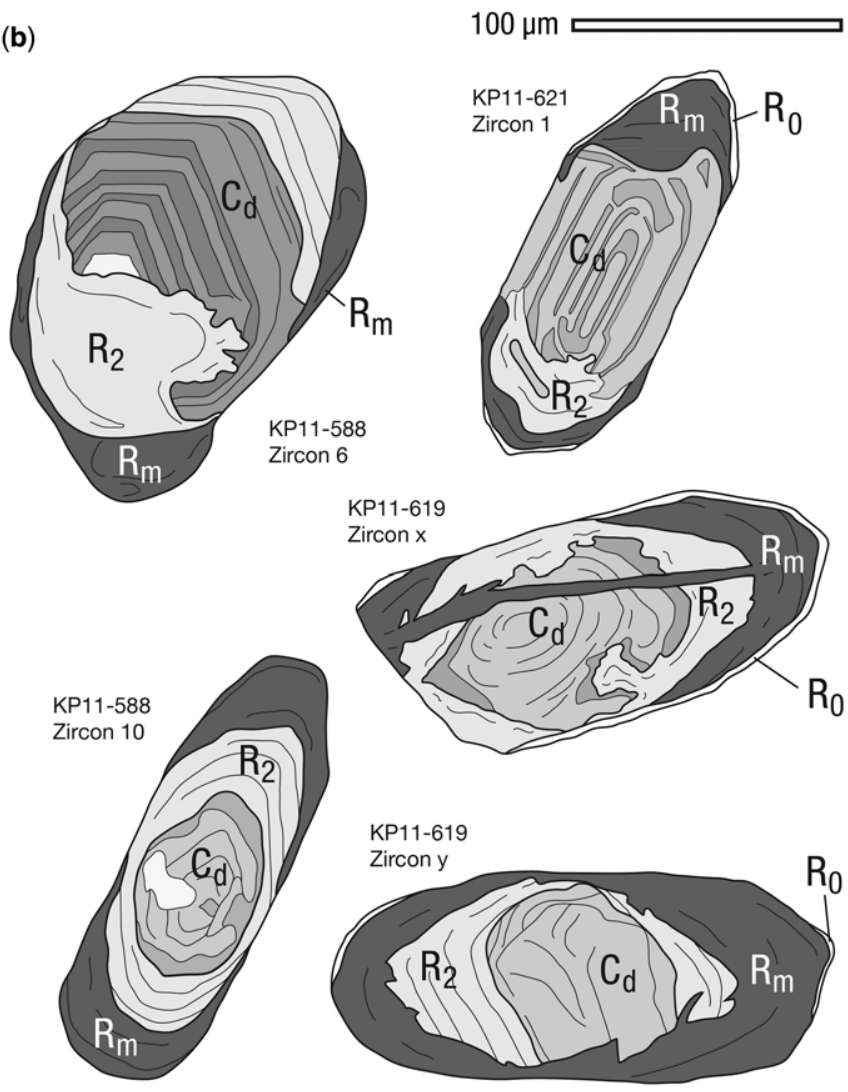

Fig. 8. (a) CL images of zircons from sample KP11-588 analysed as part of this study. Note the distinctive cores $\left(C_{d}\right)$, 1st overgrowth zones $\left(R_{2}\right)$, and CL-dark rims $\left(R_{m}\right)$. Ages follow Pownall et al. $(2017 a)$. (b) Cartoons of selected zircon grains demonstrating the relationships between the different generations of growth (after Pownall et al. 2017a). Note also the occurrence of very thin (too thin to analyse) outermost ' $\mathrm{R}_{0}$ ' zircon rims on some grains.

\section{SHRIMP U-Pb monazite geochronology}

To complement previous zircon U-Pb dating, monazite was analysed in situ from a gold-coated polished thin section of sample KP11-588 using SHRIMP-II at the RSES, ANU. Analyses were performed using a $10 \mathrm{kV}$ primary beam of $\mathrm{O}_{2}{ }^{-}$ ions focused on the sample surface over a $30 \mu \mathrm{m}$

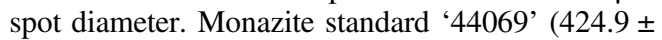
$0.4 \mathrm{Ma}$; Aleinikoff et al. 2006) was used for calibration. The data were reduced using the SQUID-2 Excel macro (Ludwig 2009) utilizing decay constants from Steiger \& Jäger (1977) and concordia diagrams were plotted using Isoplot-3 (Ludwig 2003). The correction for common $\mathrm{Pb}$ was made using ${ }^{207} \mathrm{~Pb}$ (which assumes ${ }^{206} \mathrm{~Pb} /{ }^{238} \mathrm{U}-{ }^{207} \mathrm{~Pb} /{ }^{235} \mathrm{U}$ concordance) and the relevant initial ${ }^{207} \mathrm{~Pb} /{ }^{206} \mathrm{~Pb}$ value from the model of Stacey \& Kramers (1975).

Monazite was analysed from two textural settings: (1) from a large monazite grain within the leucosome (grain 1; Fig. 6c); and (2) from a monazite inclusion within garnet (grain 2; Fig. 6d). All four analyses yielded within uncertainty the same ${ }^{206} \mathrm{~Pb} /{ }^{238} \mathrm{U}$ age (Table 2) and define an isochron date of $16.4 \pm 0.4 \mathrm{Ma}$ (Fig. 10). This date is within analytical uncertainty of the mean ${ }^{206} \mathrm{~Pb} /{ }^{238} \mathrm{U}$ age of $R_{m}$ zircon from the same sample $(16.0 \pm 0.6 \mathrm{Ma})$.

\section{Garnet and zircon geochemistry}

\section{Garnet major element chemistry}

Garnet major element chemistry was measured previously using a JEOL JXA-8100 Superprobe electron microprobe (EPMA) paired with an Oxford Instruments INCA EDS system at Birkbeck College, University of London (Pownall 2015). Mineral EPMA analyses used an accelerating voltage of $15 \mathrm{kV}$, a beam current of $10 \mathrm{nA}$, a $1 \mu \mathrm{m}$ beam 

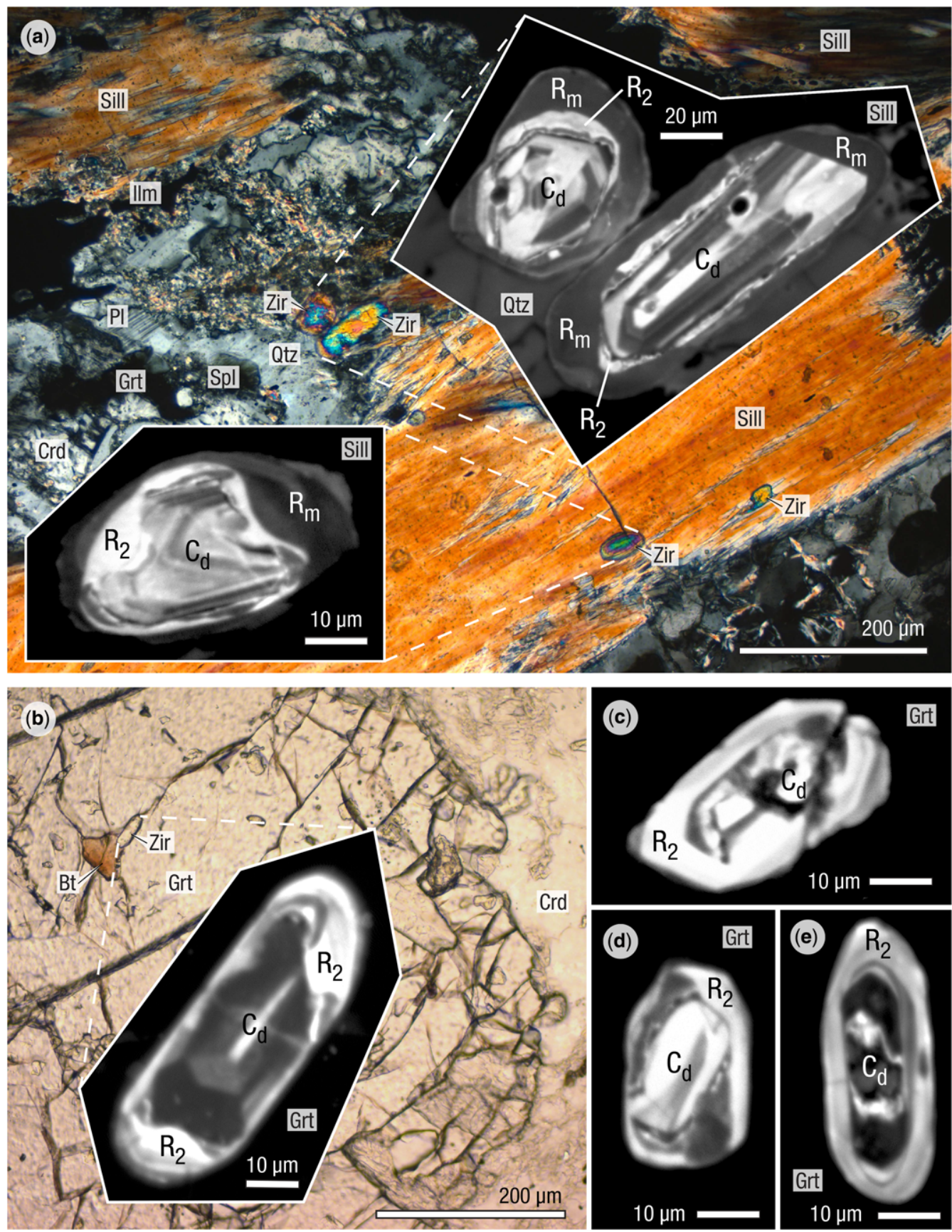

Fig. 9. CL images of zircons acquired in situ from a thin section of sample KP11-588. (a) Zircons located in the post-peak reaction microstructures at the boundary with leucosome and included with a large lath of sillimanite feature thick $\mathrm{R}_{\mathrm{m}}$ rims (dark in CL) overgrowing $\mathrm{R}_{2}$ zones (bright in CL) and detrital cores $\left(\mathrm{C}_{\mathrm{d}}\right.$ ). The CL images annotate a XPL thin section photo of the same zircon grains, showing their textural locations. (b-e) Zircons included within garnet do not feature $R_{m}$ rims, just CL-bright $R_{2}$ zones around detrital cores $\left(C_{d}\right)$. In (b), the CL image annotates a PPL thin section photo of the same zircon grain, located $>200 \mu \mathrm{m}$ from the rim of the garnet it is included in. Mineral abbreviations are after Kretz (1983). 


\section{J. M. POWNALL ET AL.}

Table 2. $U-P b$ monazite geochronology, sample KP11-588

\begin{tabular}{|c|c|c|c|c|c|c|c|c|c|c|c|c|}
\hline \multirow[t]{2}{*}{$\begin{array}{l}\text { Analytical } \\
\text { Spot }\end{array}$} & \multirow[t]{2}{*}{$\begin{array}{c}\% \\
{ }^{\%} \mathrm{~Pb}_{\mathrm{c}}\end{array}$} & \multirow[t]{2}{*}{$\begin{array}{c}\mathrm{U} \\
(\mathrm{ppm})\end{array}$} & \multirow[t]{2}{*}{$\begin{array}{l}{ }^{206} \mathrm{~Pb}^{*} \\
(\mathrm{ppm})\end{array}$} & \multirow[t]{2}{*}{${ }^{232} \mathrm{Th} /$} & \multicolumn{2}{|c|}{$\begin{array}{c}{ }^{206} \mathrm{~Pb} /{ }^{238} \mathrm{U} \\
\mathrm{Age}^{\dagger}\end{array}$} & \multicolumn{2}{|c|}{$\begin{array}{c}\text { Total } \\
{ }^{238} \mathrm{U} /{ }^{206} \mathrm{~Pb}\end{array}$} & \multicolumn{2}{|c|}{$\begin{array}{c}\text { Total } \\
{ }^{207} \mathrm{~Pb} /{ }^{206} \mathrm{~Pb}\end{array}$} & \multicolumn{2}{|c|}{${ }^{206} \mathrm{~Pb}^{*} /{ }^{238} \mathrm{U}^{\dagger}$} \\
\hline & & & & & $\mathrm{Ma}$ & $\pm 1 \sigma$ & & $\pm 1 \sigma$ & & $\pm 1 \sigma$ & & $\pm(\%)$ \\
\hline $2.1^{\ddagger}$ & 7.72 & 2494 & 32922 & 14 & 16.7 & 0.4 & 356 & 2.4 & 0.1074 & 1.4 & 0.002590 & 0.78 \\
\hline $1.1^{\S}$ & 12.80 & 541 & 51957 & 99 & 15.3 & 0.9 & 368 & 5.9 & 0.1475 & 2.8 & 0.002370 & 1.89 \\
\hline $1.2^{\S}$ & 8.72 & 457 & 54796 & 124 & 16.3 & 0.6 & 361 & 3.6 & 0.1153 & 5.3 & 0.002530 & 1.18 \\
\hline $1.3^{\S}$ & 9.45 & 793 & 86551 & 113 & 16.4 & 0.3 & 356 & 1.5 & 0.1211 & 3.2 & 0.002547 & 0.50 \\
\hline
\end{tabular}

$* \mathrm{~Pb}_{\mathrm{c}}$ and $\mathrm{Pb}$ indicate the common and radiogenic portions, respectively.

Common $\mathrm{Pb}$ corrected by assuming ${ }^{206} \mathrm{~Pb} /{ }^{238} \mathrm{U}-{ }^{207} \mathrm{~Pb} /{ }^{235} \mathrm{U}$ age-concordance.

Intra-garnet monazite.

${ }^{\S}$ Matrix monazite.

diameter and were calibrated using natural silicate and oxide standards before a ZAF correction procedure was applied.

As shown in Figure 11, broad and compositionally homogeneous garnet core regions are dominantly an almandine-pyrope solid solution $\left(X_{\mathrm{alm}} c\right.$. $\left.0.60 ; X_{\mathrm{pyr}} c .0 .30 ; X_{\mathrm{sps}} c .0 .06 ; X_{\mathrm{grs}} c .0 .04\right)$. Moderate zoning is present in the outermost margin, with almandine increasing $\left(X_{\mathrm{alm}}\right.$ rising from 0.60 to $0.68)$ and pyrope decreasing $\left(X_{\mathrm{pyr}}\right.$ falling from 0.30 to 0.17$)$ moving towards the rim. The replacement of original garnet rims by cordierite coronae during high- $T$ retrogression (Fig. 3e) is further evidenced by the truncation of garnet-zoning profiles, as shown by the backscatter intensity map in Figure 11b. A sharp increase of Mn (spessartine)

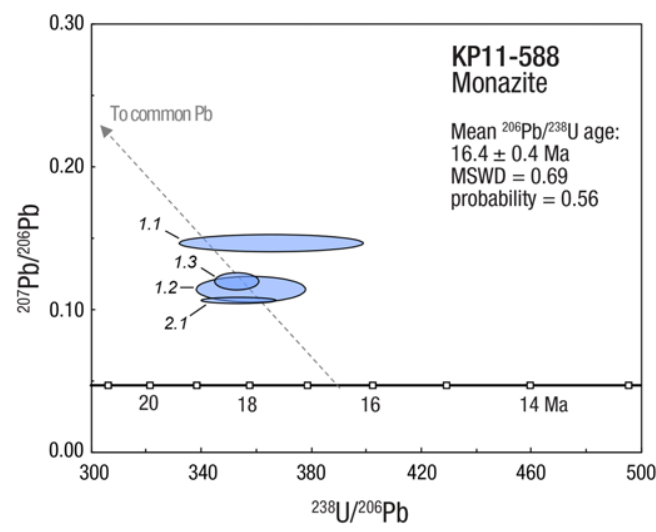

Fig. 10. Tera-Wasserburg plot for SHRIMP U-Pb analysis of monazite from sample KP11-588. The mean ${ }^{206} \mathrm{~Pb} /{ }^{238} \mathrm{U}$ age is quoted to $95 \%$ confidence, and error ellipses are drawn at $68.3 \%$ confidence. An upper intercept (common $\mathrm{Pb}{ }^{207} \mathrm{~Pb} /{ }^{206} \mathrm{~Pb}$ ) value of 0.837 is based on the model of Stacey \& Kramers (1975).

MSWD, mean square of weighted deviates. See Table 2 for U-Pb geochronology data. close to the rim demonstrates that garnet resorption occurred during cordierite corona development.

\section{Garnet REE analysis}

REE zonation profiles for several garnets in sample KP11-588 were measured in situ from a polished thin section by rim-to-core-to-rim laser traverses using the RESOlution M-50 $193 \mathrm{~mm}$ ArF excimer laser $(40 \mu \mathrm{m}$ spot size) coupled to an Aglient 7500ce LA-ICP-MS system (Müller et al. 2009) at Royal Holloway, University of London (RHUL). NIST SRM-612 glass was used as an external standard. The variation in $\mathrm{Lu}, \mathrm{Hf}, \mathrm{Sm}$ and $\mathrm{Nd}$ for one of these traverses is shown in Figure 12 and the full range of REE abundances is plotted in Figure 13. The full dataset is included in the Supplementary material.

These REE profiles demonstrate the occurrence of chemically-distinct core regions (shaded grey in Fig. 12), which interestingly are not shown by the major element distributions. Core REE concentrations are substantially higher $(>\times 10)$ than those of the rims (e.g. $c .1 \mathrm{ppm}{ }^{175} \mathrm{Lu}$ in the rim; c. $30 \mathrm{ppm}$ ${ }^{175} \mathrm{Lu}$ in the core). In the example shown in Figure 12, the diameter of the garnet core is c. $45 \%$ of the entire crystal and so volumetrically the core regions represent only c. $9 \mathrm{vol} \%$ of the garnet as a whole (or even smaller if considering that the outermost garnet rims have since been consumed to produce the cordierite + spinel coronae).

\section{Zircon REEs and Ti}

SHRIMP II at Geoscience Australia, Canberra, was used to analyse $\mathrm{R}_{\mathrm{m}}$ and $\mathrm{R}_{2}$ zircon from samples KP11-588 and KP11-619 for Ti and REE abundances. These analyses used the same zircon mount that was used previously for $\mathrm{U}-\mathrm{Pb}$ geochronology and so zircon grains and analytical spots correlate with those reported by Pownall et al. (2017a). 


\section{MIOCENE UHT GRANULITES FROM SERAM}
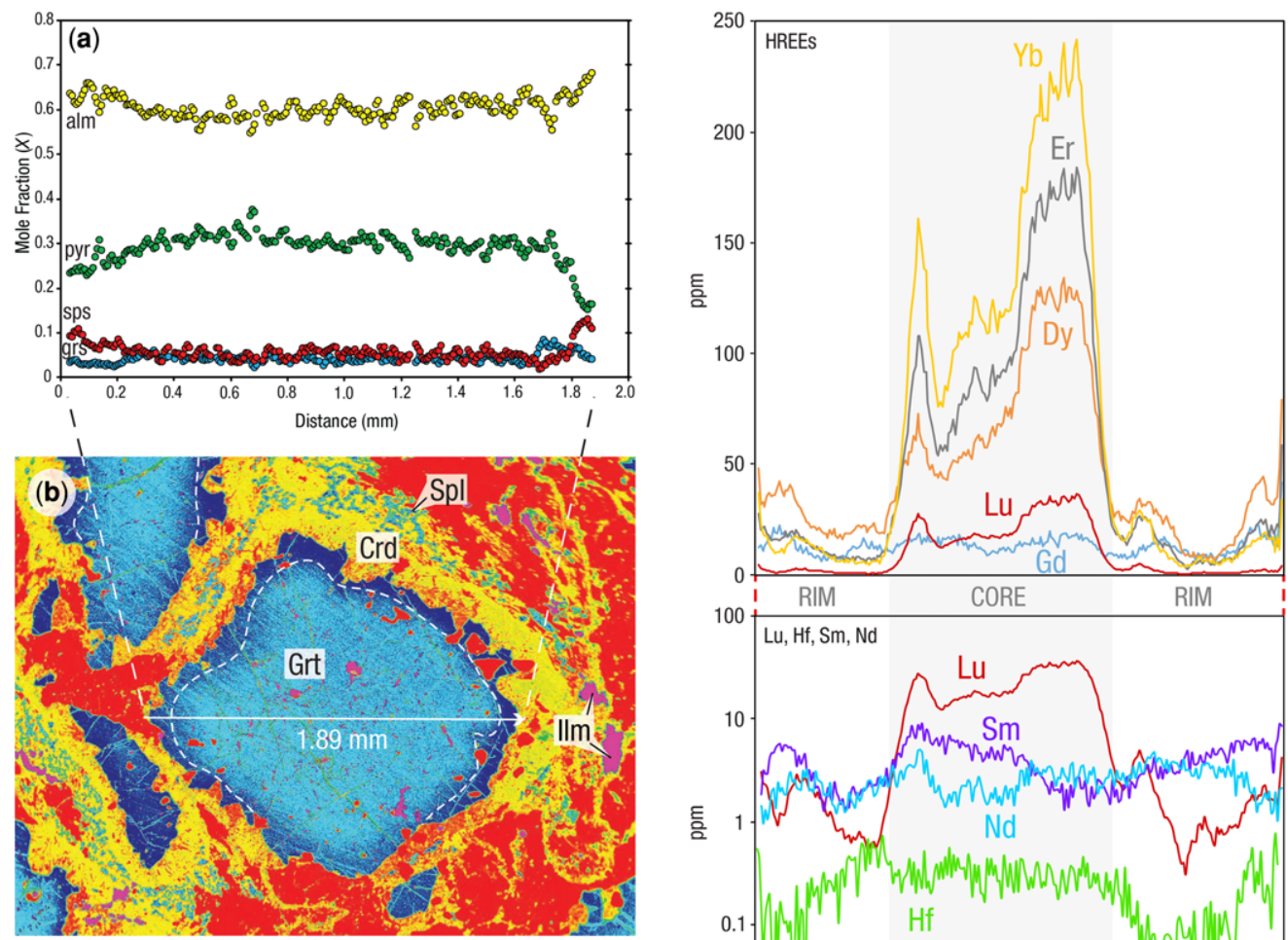

Fig. 11. (a) Major element zonation profile through representative garnet in sample KP11-588 determined from electron microprobe line-scan (modified after Pownall 2015). Garnet composition is expressed in terms of the following end-members: almandine $(\mathrm{alm})=\mathrm{Fe}^{2+} /$ $\left(\mathrm{Fe}^{2+}+\mathrm{Mn}+\mathrm{Mg}+\mathrm{Ca}\right)$; pyrope (pyr) $=\mathrm{Mg} /\left(\mathrm{Fe}^{2+}+\right.$ $\mathrm{Mn}+\mathrm{Mg}+\mathrm{Ca}) ;$ spessartine $(\mathrm{sps})=\mathrm{Mn} /\left(\mathrm{Fe}^{2+}+\mathrm{Mn}+\right.$ $\mathrm{Mg}+\mathrm{Ca})$; grossular $($ grs $)=\mathrm{Ca} /\left(\mathrm{Fe}^{2+}+\mathrm{Mn}+\mathrm{Mg}+\mathrm{Ca}\right)$. The location of this line-scan is shown in (b) - a backscattered electron image coloured according to backscatter intensity that displays the geometry of the major element garnet zonation profile. Major element concentrations are flat in the central region, displaying evidence for resorption close to the rim (with increase in spessartine component). Unlike as depicted by HREE zoning (Fig. 12), there is no evidence for a separate core region.

For these analyses, a $10 \mathrm{kV}$ primary $\mathrm{O}_{2}{ }^{-}$ion beam was used to ablate spots $c .25 \mu \mathrm{m}$ diameter. Positive secondary ions were extracted at $10 \mathrm{kV}$ and mass analysed at approximately R5000. Moderate energy filtering of the secondary ions (c. $20 \%$ transmission of ${ }^{91} \mathrm{Zr}$ ) was used to reduce the contribution of potential isobaric interferences, particularly from light REE (LREE) oxides. All REE were measured and for those REE that were not monoisotopic, two isotopes were measured as a check on accuracy. Other isotopes analysed were ${ }^{49} \mathrm{Ti}$ (for
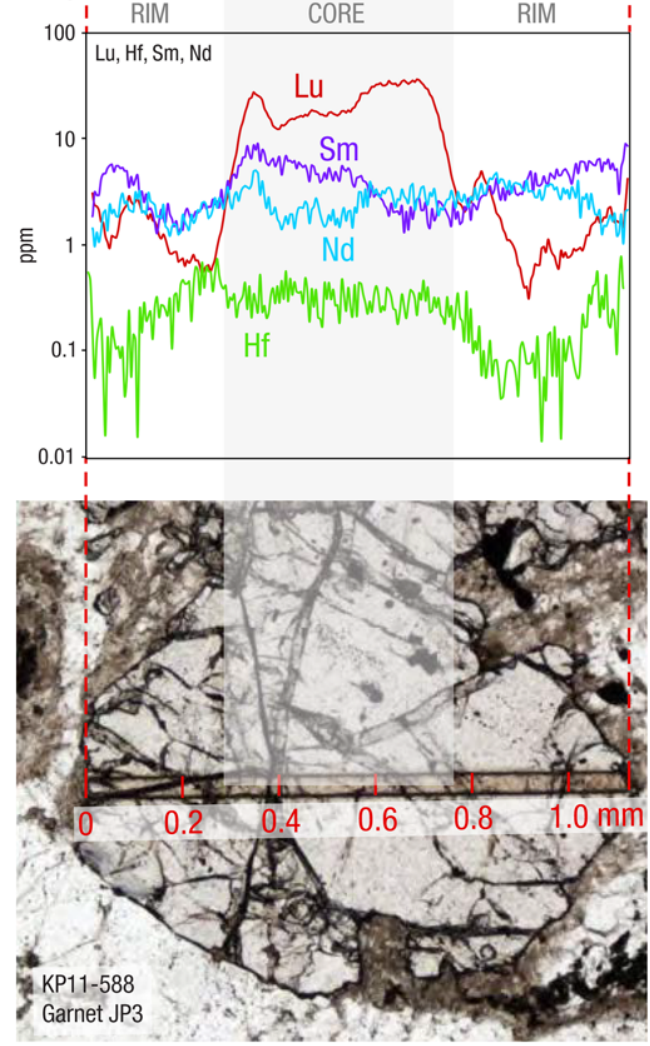

Fig. 12. HREE abundances (linear scale) and concentrations of $\mathrm{Lu}, \mathrm{Sm}, \mathrm{Nd}$, and $\mathrm{Hf}$ (log scale) obtained along a $1.1 \mathrm{~mm}$ LA-ICP-MS laser traverse through garnet from KP11-588 (ablation track through garnet shown at bottom). The HREE profiles demonstrate the occurrence of a distinct core region (shaded grey), but it was unfortunately not possible to manually separate garnet cores and rims for the $\mathrm{Lu}-\mathrm{Hf}$ and $\mathrm{Sm}-\mathrm{Nd}$ dating. Three additional laser transects (not shown) were performed, with similar results. See the Supplementary material for the full dataset. 


\section{J. M. POWNALL ET AL.}

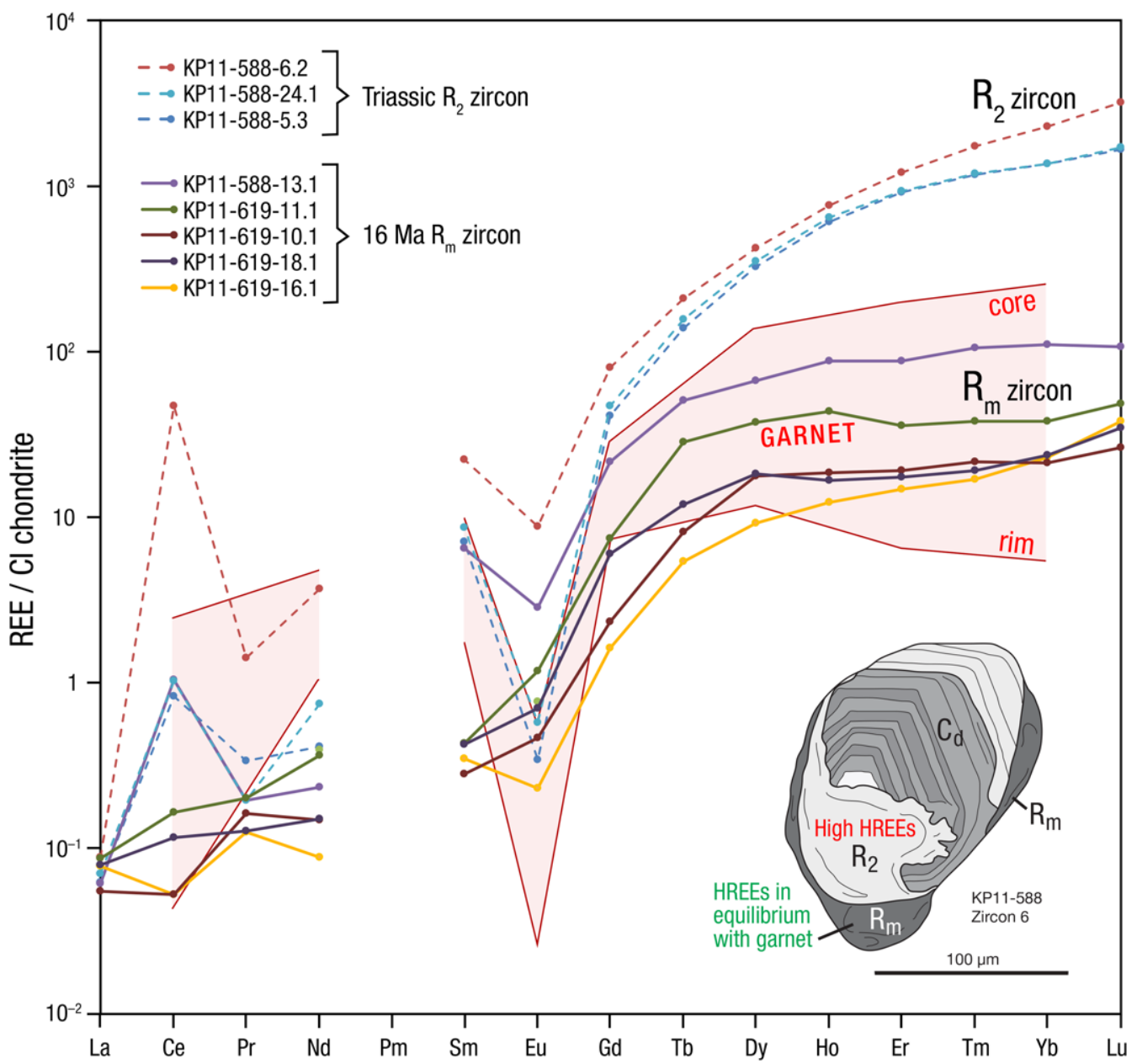

Fig. 13. REE plot comparing $R_{m}$ zircon, $R_{2}$ zircon and garnet. Zircon from samples KP11-588 and KP11-619 was analysed by SHRIMP II at Geoscience Australia and the garnet data were acquired by LA-ICP-MS laser transects (Fig. 12), as described in the text. The concentrations are normalised to CI chondrite values (McDonough \& Sun 1995). The broad spread in garnet HREE concentrations is due to the differences in abundance between the core (relatively enriched) and rim (relatively depleted), as labelled (and evident in Fig. 12). This plot shows that HREE abundances of $c .16 \mathrm{Ma} \mathrm{R}_{\mathrm{m}}$ zircon are within the range of garnet HREE abundances, but the $c .200 \mathrm{Ma} \mathrm{R}_{2}$ zircon concentrations are an order of magnitude higher. See the Supplementary material for full datasets.

the Ti-in-zircon thermometry), ${ }^{46} \mathrm{SiO}$ (to ensure accurate location of the ${ }^{49} \mathrm{Ti}$ peak), ${ }^{91} \mathrm{Zr}$ (as a reference for calculating the REE concentrations) and two Hf isotopes (for the calculation of $\mathrm{Zr} / \mathrm{Hf}$ ). Relative sensitivity factors for $\mathrm{Ti}$, the REE and Hf were calculated from an initial analysis of NIST611 glass and SL13 and Temora 2 zircons were analysed as secondary standards. Each analysis consisted of three scans through the isotopes of interest, which took 15 minutes. The data were reduced using an in-house Excel spreadsheet. Analytical uncertainties ranged from $c$. $\pm 2 \mathrm{ppb}$ for REE isotopes with low concentrations $(<20 \mathrm{ppb})$ to $c . \pm 0.2 \mathrm{ppm}$ for REE isotopes with high concentrations $(>50 \mathrm{ppm})$.

Eight sets of analyses were acquired from the two samples: one $\mathrm{R}_{\mathrm{m}}$ zircon rim and three $\mathrm{R}_{2}$ zircon zones for sample KP11-588, and four $R_{m}$ zircon rims for sample KP11-619 (see Supplementary material). As shown in Figure $13, R_{m}$ and $R_{2}$ zircon have very distinct REE profiles: (1) $R_{2}$ zircon has over an order of magnitude greater enrichment in the heavy REEs (HREEs) than $\mathrm{R}_{\mathrm{m}}$ zircon (e.g. maxima of $78 \mathrm{ppm} \mathrm{Lu}$ for $\mathrm{R}_{2}$ and $3 \mathrm{ppm}$ for $\mathrm{R}_{\mathrm{m}}$ ), and (2) $R_{m}$ zircon has notably flatter LREE profiles than $R_{2}$. 


\section{MIOCENE UHT GRANULITES FROM SERAM}

\section{Zircon Th/U ratios}

For the Kobipoto Mountains granulite samples, $\mathrm{R}_{\mathrm{m}}$ zircon rims all have $\mathrm{Th} / \mathrm{U}$ ratios $<0.1$ (Fig. 14). Assuming that the $\mathrm{Th} / \mathrm{U}$ values in this instance can be considered a reliable discriminator of magmatic $v$. metamorphic zircon, where $\mathrm{Th} / \mathrm{U}<0.1$ suggests a metamorphic origin (Rubatto 2002), then the $\mathrm{R}_{\mathrm{m}}$ rims for the granulites exclusively plot in the "metamorphic zone'. The detrital cores have higher $\mathrm{Th} / \mathrm{U}$ ratios than the rims, some of them surpassing 1 . The $\mathrm{R}_{2}$ zircon zones display a wide spread in $\mathrm{Th} / \mathrm{U}$ ratios that mostly plot in the 'metamorphic' field $(\mathrm{Th} / \mathrm{U}<$ 0.1 ) but some analyses show similar values to the detrital cores (Th/U approaching 1).

Since different populations of zircon are consistently grouped based on their $\mathrm{Th} / \mathrm{U}$ ratios and zircons with known magmatic origin have the highest values, we consider it likely that the $c .16 \mathrm{Ma} \mathrm{R}_{\mathrm{m}}$ zircon rims with notably lower $\mathrm{Th} / \mathrm{U}$ ratios crystallized during a metamorphic episode, in accordance with previous conclusions (Pownall et al. 2014, 2017a). To a lesser extent, this trend is also indicative of the $\mathrm{R}_{2}$ zircon being also metamorphic in origin.

\section{Zircon-rutile thermometry}

Following Ferry \& Watson (2007), the exchanges of $\mathrm{Ti}^{4+}$ between zircon and rutile (and/or other

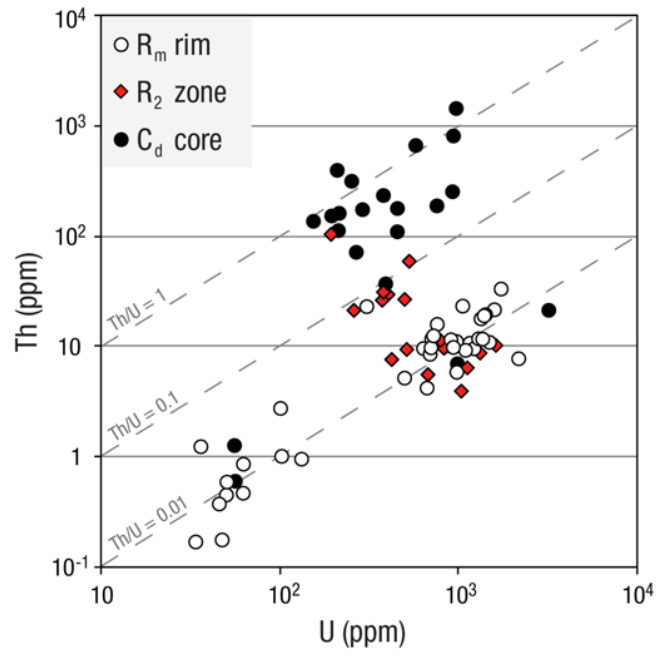

Fig. 14. Th v. U plots of zircon from samples KP11-588, KP11-691, and KP11-621 analysed by SHRIMP (Pownall et al. 2017a). KP11-621 is a Kobipoto Complex cordierite diatexite also from the Kobipoto Mountains (see Table 1). Grey dashed lines contour fixed $\mathrm{Th} / \mathrm{U}$ ratios. Analyses are coloured according to the type of zircon analysed: black circles for detrital cores $\left(C_{d}\right)$; white circles for metamorphic overgrowths $\left(\mathrm{R}_{\mathrm{m}}\right)$; diamonds for CL-bright ' $\mathrm{R}_{2}$ ' zones.
Ti-bearing phases) and of $\mathrm{Zr}^{4+}$ between rutile and zircon (and/or other Zr-bearing phases) may be utilized as geothermometers. As zircon and rutile grains occur in the same microtextural domains - both as inclusions within garnet and in the leucosomes of the Kobipoto Complex granulites (Figs 6 \& 9) - it is reasonable to assume in this instance that rutile and zircon were in (or close to) equilibrium.

\section{Ti-in-zircon thermometry}

Using the Ti abundances acquired to high precision by SHRIMP (methodology detailed in previous section), the Ti-in-zircon thermometry calibrations of Watson et al. (2006) and Ferry \& Watson (2007) were applied to granulite samples KP11-588 and KP11-619 (Fig. 15; Table 3). Based on the Ferry \& Watson (2007) thermometer, $\mathrm{R}_{\mathrm{m}}$ zircons crystallized at temperatures of $c .600^{\circ} \mathrm{C}\left(540-640^{\circ} \mathrm{C}\right)$ and $\mathrm{R}_{2} \mathrm{zir}-$ con at slightly higher temperatures of $c .700^{\circ} \mathrm{C}(660$ $750^{\circ} \mathrm{C}$ ). The Watson et al. (2006) thermometer gave similar temperatures, but with much larger positive uncertainties (of $+200^{\circ} \mathrm{C}$ ).

Despite these samples having attained peak metamorphic temperatures of $c .925^{\circ} \mathrm{C}$, neither $\mathrm{R}_{\mathrm{m}}$ nor $\mathrm{R}_{2}$ zircon shows evidence for having crystallized under or even close to UHT conditions. One possible reason for these lower-than-expected temperatures is if $a \mathrm{TiO}_{2}$, assumed here to be 1.0 , was overestimated (Yakymchuk et al. 2017). Although there is evidence in this instance for rutile and zircon co-inhabiting the same domains of the rock, it is still possible that a lower $a \mathrm{TiO}_{2}$ was in operation. For a metapelite of broadly similar composition to the Seram UHT granulites and for similar $P-T$ conditions to the formation of their post-peak reaction microstructures $\left(900^{\circ} \mathrm{C}\right.$ and $7 \mathrm{kbar}$, with melt present), Yakymchuk et al. (2017) calculated an $a \mathrm{TiO}_{2}$ value of $c$. 0.7. However, using this lower $a \mathrm{TiO}_{2}$ value raised our Ferry \& Watson (2007) Ti-in-zircon temperatures by only c. $30^{\circ} \mathrm{C}-$ a long way short of raising these estimates to peak UHT conditions.

These results imply that $R_{m}$ metamorphic zircon must have crystallized during retrogression after the peak of UHT metamorphism (so at $600^{\circ} \mathrm{C}$ and c. $3 \mathrm{kbar}$, based on the $P-T$ path inferred by Pownall 2015) and not under peak metamorphic conditions (even if a much lower $a \mathrm{TiO}_{2}$ value were used). Temperatures of $c .700^{\circ} \mathrm{C}$ for the $\mathrm{R}_{2}$ zircon are consistent with either a high-grade metamorphic or a magmatic origin during crystallization at $c .200 \mathrm{Ma}$ (with low $\mathrm{Th} / \mathrm{U}$ ratios indicative of the former; Fig. 14).

\section{Zr-in-rutile thermometry}

Rutile was analysed in situ from a polished thin section (most grains $<30 \mu \mathrm{m}$ ) using a $193 \mathrm{~nm}$ Coherent excimer laser (focused to a $13 \mu \mathrm{m}$ beam diameter) 


\section{J. M. POWNALL ET AL.}

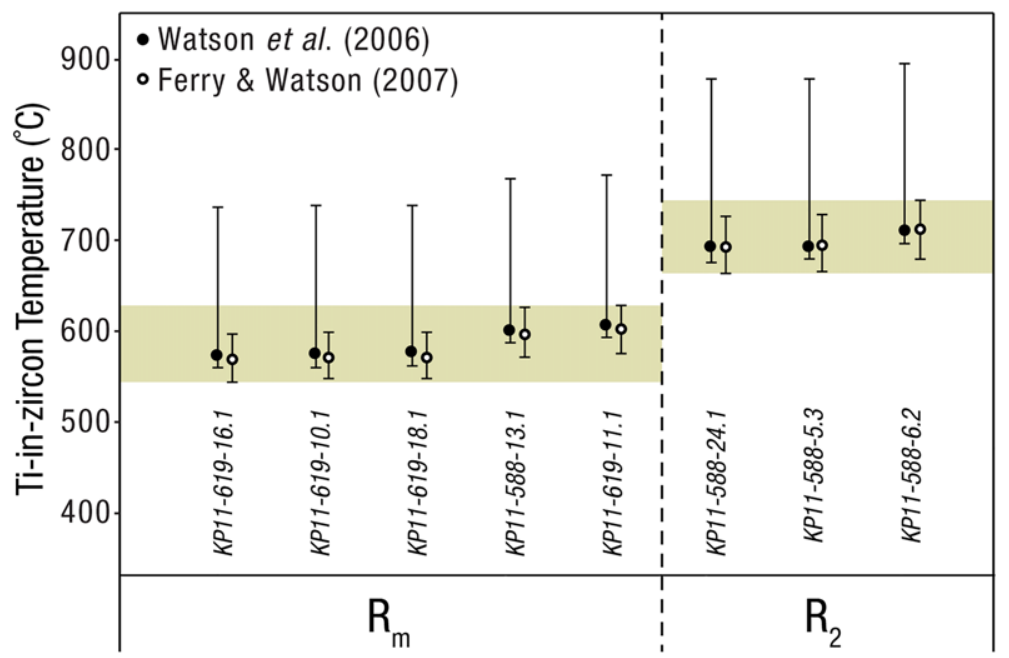

Fig. 15. Results of Ti-in-zircon thermometry acquired for zircon from samples KP11-588 and KP11-619. The shaded regions are drawn for the Ferry \& Watson (2007) calibration and demonstrate a notable difference in temperature between $\mathrm{R}_{\mathrm{m}}$ zircon $\left(c .600^{\circ} \mathrm{C}\right)$ and $\mathrm{R}_{2}$ zircon $\left(c .700^{\circ} \mathrm{C}\right)$. The activities of $\mathrm{SiO}_{2}$ and $\mathrm{TiO}_{2}$ were assumed here to both equal 1 for application of the Ferry \& Watson (2007) thermometer (although lowering $a \mathrm{SiO}_{2}$ by 0.1 lowers temperatures by $c .15^{\circ} \mathrm{C}$ ). See Table 3 for Ti concentrations and full thermometry results.

coupled to a Aglient 7700 ICP-MS at the RSES, ANU. NIST-610 glass was used as the primary standard and NIST-612 and BCR-2G glasses were used as secondary standards. Data were reduced using Iolite software (Paton et al. 2011) following the 'semi-quantitative' data reduction scheme.

Twenty analyses were acquired (after discarding misplaced spots) for rutiles occurring as inclusions within garnet and adjacent to garnet from within the cordierite-dominated coronae. Zr-in-rutile temperatures were calculated using the Ferry \& Watson (2007) and Tomkins et al. (2007) thermometers for an $a \mathrm{SiO}_{2}$ of 1 and a pressure of 9 kbar. Both calibrations yielded identical results within uncertainty (Table 4).

Figure 16 shows the results of the Tomkins et al. (2007) thermometer. The most $\mathrm{Zr}$-rich rutile grain $(3816 \pm 365 \mathrm{ppm} \mathrm{Zr}$; Fig. 6f) corresponds to a $\mathrm{Zr}$-in-rutile temperature of $907 \pm 14^{\circ} \mathrm{C}$. A total of three analyses indicated temperatures in the vicinity of $900^{\circ} \mathrm{C}$, although most temperatures fall between 600 and $750^{\circ} \mathrm{C}$ (Fig. 16). Interestingly, those highest temperatures were recorded by rutile grains within the leucosome, with rutile included in garnet

Table 3. Ti-in-zircon thermometry

\begin{tabular}{|c|c|c|c|c|c|c|c|c|c|}
\hline \multirow[t]{2}{*}{ Analytical spot } & \multirow[t]{2}{*}{ Zircon type } & \multirow[t]{2}{*}{$\mathrm{Ti}(\mathrm{ppm})$} & \multirow[t]{2}{*}{ \pm} & \multicolumn{3}{|c|}{$\begin{array}{l}\text { Watson et al. }(2006) \\
\text { thermometer }\end{array}$} & \multicolumn{3}{|c|}{$\begin{array}{c}\text { Ferry \& Watson } \\
\text { (2007) thermometer* }\end{array}$} \\
\hline & & & & $T\left({ }^{\circ} \mathrm{C}\right)$ & + & - & $T\left({ }^{\circ} \mathrm{C}\right)$ & + & - \\
\hline KP11-619-16.1 & $\mathrm{R}_{\mathrm{m}}$ & 1.01 & 0.05 & 573 & 164 & 12 & 568 & 29 & 22 \\
\hline KP11-619-10.1 & $\mathrm{R}_{\mathrm{m}}$ & 1.05 & 0.08 & 575 & 165 & 14 & 570 & 31 & 21 \\
\hline KP11-619-18.1 & $\mathrm{R}_{\mathrm{m}}$ & 1.06 & 0.06 & 576 & 165 & 13 & 571 & 30 & 22 \\
\hline KP11-588-13.1 & $\mathrm{R}_{\mathrm{m}}$ & 1.56 & 0.06 & 600 & 168 & 12 & 597 & 30 & 24 \\
\hline KP11-619-11.1 & $\mathrm{R}_{\mathrm{m}}$ & 1.68 & 0.03 & 605 & 167 & 11 & 602 & 29 & 26 \\
\hline KP11-588-24.1 & $\mathrm{R}_{2}$ & 5.54 & 0.24 & 692 & 187 & 15 & 693 & 36 & 27 \\
\hline KP11-588-5.3 & $\mathrm{R}_{2}$ & 5.67 & 0.16 & 693 & 186 & 13 & 695 & 34 & 29 \\
\hline KP11-588-6.2 & $\mathrm{R}_{2}$ & 6.88 & 0.12 & 709 & 188 & 13 & 712 & 34 & 30 \\
\hline
\end{tabular}

Results of Ti-in-zircon thermometry applied to $\mathrm{R}_{\mathrm{m}}$ and $\mathrm{R}_{2}$ zircon from sample KP11-619 and KP11-588. Ti concentrations were measured using SHRIMP II at Geoscience Australia. See Figure 15 for a graphical representation of these data.

$*$ Assuming that $a \mathrm{SiO}_{2}=a \mathrm{TiO}_{2}=1$. 
Downloaded from http://sp.lyellcollection.org/ by guest on April 23, 2018

MIOCENE UHT GRANULITES FROM SERAM

Table 4. Zr-in-rutile thermometry

\begin{tabular}{|c|c|c|c|c|c|c|c|c|c|}
\hline \multirow[t]{2}{*}{ Analytical spot } & \multirow[t]{2}{*}{ Rutile location } & \multirow[t]{2}{*}{$\mathrm{Zr}(\mathrm{ppm})$} & \multirow[t]{2}{*}{ \pm} & \multicolumn{3}{|c|}{$\begin{array}{l}\text { Ferry \& Watson } \\
\text { (2007) thermometer* }\end{array}$} & \multicolumn{3}{|c|}{$\begin{array}{c}\text { Tomkins et al. }(2007) \\
\text { thermometer }^{\dagger}\end{array}$} \\
\hline & & & & $T\left({ }^{\circ} \mathrm{C}\right)$ & + & - & $T\left({ }^{\circ} \mathrm{C}\right)$ & + & - \\
\hline $\mathrm{rt} 1$ & in leucosome $e^{\ddagger}$ & 3816 & 365 & 907 & 12 & 13 & 907 & 12 & 13 \\
\hline $\mathrm{rt} 7$ & in leucosome & 3269 & 365 & 887 & 14 & 15 & 887 & 14 & 15 \\
\hline rt6 & in leucosome & 3138 & 333 & 882 & 13 & 14 & 882 & 13 & 14 \\
\hline $\mathrm{rt} 28$ & in Grt & 1569 & 118 & 799 & 8 & 9 & 800 & 8 & 8 \\
\hline $\mathrm{rt} 29$ & in Grt & 1053 & 140 & 757 & 13 & 14 & 758 & 13 & 14 \\
\hline $\mathrm{rt17}$ & in Grt; adj. Ilm & 852 & 90 & 736 & 10 & 11 & 737 & 10 & 11 \\
\hline $\mathrm{rt} 27$ & in Grt & 806 & 82 & 731 & 9 & 10 & 732 & 9 & 10 \\
\hline $\mathrm{rt} 14$ & in Grt; adj. Ilm & 614 & 47 & 705 & 7 & 7 & 706 & 7 & 7 \\
\hline $\mathrm{rt} 11$ & in Grt; adj. Ilm & 601 & 51 & 703 & 7 & 8 & 705 & 7 & 8 \\
\hline $\mathrm{rt13}$ & in Grt; adj. Ilm & 583 & 60 & 700 & 9 & 10 & 702 & 9 & 10 \\
\hline $\mathrm{rt} 15$ & in Grt & 544 & 46 & 694 & 7 & 8 & 696 & 7 & 8 \\
\hline $\mathrm{rt} 12$ & in Grt; adj. Ilm & 513 & 77 & 689 & 13 & 14 & 690 & 13 & 14 \\
\hline $\mathrm{rt} 4$ & in Grt & 451 & 161 & 678 & 27 & 37 & 679 & 27 & 37 \\
\hline $\mathrm{rt} 16$ & in Grt & 413 & 33 & 670 & 7 & 7 & 672 & 7 & 7 \\
\hline $\mathrm{rt} 5$ & in Grt & 302 & 45 & 644 & 11 & 13 & 646 & 11 & 13 \\
\hline $\mathrm{rt} 33$ & in Grt; adj. Ilm & 270 & 33 & 635 & 9 & 10 & 637 & 9 & 10 \\
\hline $\mathrm{rt} 24$ & in Grt; adj. Ilm & 256 & 23 & 631 & 7 & 7 & 633 & 7 & 7 \\
\hline $\mathrm{rt} 25$ & in Grt; adj. Ilm & 201 & 13 & 612 & 5 & 5 & 614 & 5 & 5 \\
\hline $\mathrm{rt} 3$ & in Grt & 154 & 17 & 593 & 8 & 8 & 595 & 8 & 8 \\
\hline $\mathrm{rt} 2$ & in Grt & 149 & 30 & 591 & 13 & 16 & 593 & 13 & 16 \\
\hline
\end{tabular}

Results of Zr-in-rutile thermometry for sample KP11-588 only. Zr concentrations were measured by LA-ICP-MS at the RSES, ANU. Uncertainties are given to 2 standard errors. adj. - adjacent to. See Figure 16 for a graphical representation of these data.

*Assuming that $a \mathrm{SiO}_{2}=1$.

${ }^{\dagger}$ For $P=9 \mathrm{kbar}$.

${ }^{\ddagger}$ At the leucosome margin, also in direct contact with garnet (see Fig. 6f).

(e.g. Fig. 6e) recording the significantly lower temperatures. These hottest rutile grains indicate temperatures consistent with having recorded peak metamorphic conditions of $925^{\circ} \mathrm{C}$ and $9 \mathrm{kbar}$ (Pownall 2015).

\section{Lu-Hf and Sm-Nd garnet geochronology}

\section{Garnet preparation for isotope dilution}

Garnets were separated from the melanosome of sample KP11-588 at RHUL from a $63-250 \mu \mathrm{m}$ diameter crushed rock fraction (the same fraction from which the zircon was separated) using sodium polytungstate heavy-liquid flotation, Frantz magnetic separation and hand picking beneath a binocular microscope. Care was taken to select the most inclusion-free garnet fragments. As it was unfortunately not possible during hand-picking to distinguish whether a single garnet fragment belonged to a core or to a rim (there was no discernible difference in colour or texture, despite the garnet being chemically zoned most notably in HREEs), the separated garnet fragments were arbitrarily split into two fractions (grt-1: $54.9 \mathrm{mg}$; grt-2: $73.5 \mathrm{mg}$ ), assuming that each fraction would contain similar, but not identical, trace element abundances. A whole-rock powder of sample KP11-588 (w.r.: $92.2 \mathrm{mg}$ ), prepared in a tungsten carbide mill at RHUL, was also analysed in order to calculate garnet ages.

\section{Analytical procedures}

The methods for sample preparation and analysis largely followed those of Anczkiewicz \& Thirlwall (2003) and Bird et al. (2013). The REE zoning profiles (Fig. 12) were used to estimate the approximate abundances of $\mathrm{Sm}, \mathrm{Nd}, \mathrm{Lu}$ and $\mathrm{Hf}$ in the garnet cores in order to calculate the optimum $\mathrm{Lu}$ / $\mathrm{Hf}$ and $\mathrm{Sm} / \mathrm{Nd}$ spike weights. These spikes were added to the samples prior to full dissolution in HF and $\mathrm{HNO}_{3}$.

The samples were spiked, leached and dissolved following the procedures outlined by Anczkiewicz \& Thirlwall (2003), although in this instance $\mathrm{H}_{2} \mathrm{SO}_{4}$ leaching was not performed due to the scarcity of phosphate inclusions within the garnet (small monazite grains, which are relatively scarce, are the only phosphate inclusions). The samples were passed through Bio-Rad AG 50W-X8 cation resin to remove sequentially the high field strength elements (HFSEs), the LREEs and the HREEs. Eichrom LN resin was used subsequently to separate $\mathrm{Lu}, \mathrm{Hf}, \mathrm{Sm}$ and $\mathrm{Nd}$ from the different fractions collected from 


\section{J. M. POWNALL ET AL.}

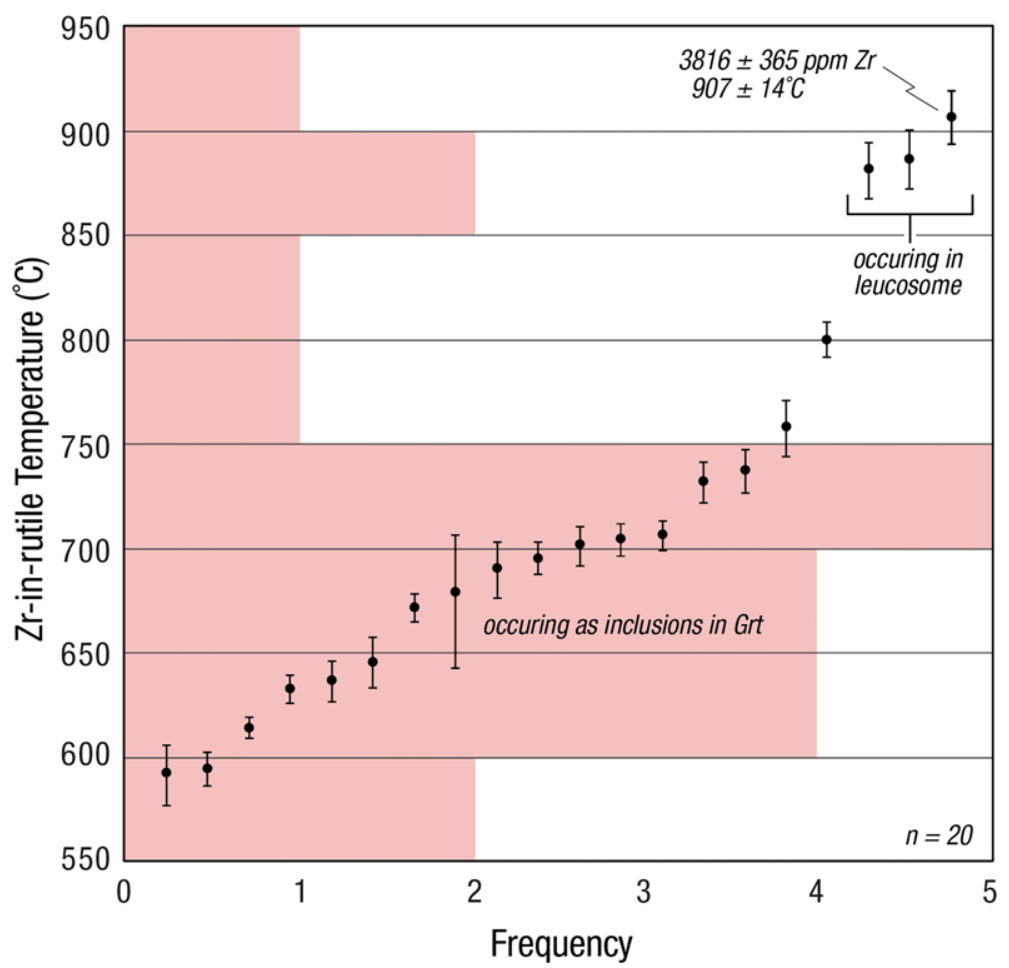

Fig. 16. Results of Zr-in-rutile thermometry (of Tomkins et al. 2007) calculated for rutile from sample KP11-588. Pressure was set at $9 \mathrm{kbar}$ in order to correspond to the peak metamorphic $P-T$ conditions calculated by Pownall (2015). The Ferry \& Watson (2007) $\mathrm{Zr}$-in-rutile thermometers (assuming $a \mathrm{SiO}_{2}=1$ ) gave extremely similar results (Table 4), which for clarity have not been plotted. The overlaid histogram (red bars) is binned at $50^{\circ} \mathrm{C}$ intervals. The three rutile grains analysed from the leucosome (Fig. 6f) yielded the hotter temperatures than those included in garnet (Fig. 6e).

the cation columns. These final solutions were analysed by the GV IsoProbe MC-ICP-MS system at RHUL, using procedures outlined by Anczkiewicz \& Thirlwall (2003). Isochron ages were calculated using IsoPlot v. 2.47 (Ludwig 2003) using decay constants of $1.865 \times 10^{-11} \mathrm{a}^{-1}$ for ${ }^{176} \mathrm{Lu}$ (Scherer et al. 2000) and $6.54 \times 10^{-12} \mathrm{a}^{-1}$ for ${ }^{147} \mathrm{Sm}$ (Lugmair \& Marti 1978). In addition, two Nd samples were analysed on the IsotopX Phoenix thermal ionization mass spectrometer (TIMS) at RHUL, to confirm the small variations in $\mathrm{Nd}$ isotopic compositions.

\section{Lu-Hf and Sm-Nd geochronology results}

Garnets analysed from UHT granulite sample KP11-588 yielded precise Lu-Hf ages of 138.6 \pm $0.7 \mathrm{Ma}$ and $137 \pm 0.6 \mathrm{Ma}$ calculated for grt- 1 and grt-2 fractions and the whole rock (i.e. 2-point isochrons), respectively (Fig. 17a; Table 5).

The Sm-Nd age is poorly constrained due to LREE-rich inclusions dominating the $\mathrm{Nd}$ budget of the analysed garnet, resulting in very small differences in measured ${ }^{143} \mathrm{Nd} /{ }^{144} \mathrm{Nd}$ ratios between the garnet and whole rock. It was not possible to construct a meaningful 3-point isochron (Fig. 17b). $\mathrm{Sm}-\mathrm{Nd}$ ages calculated individually from grt-1 and grt-2 fractions are $6.0 \pm 14.0 \mathrm{Ma}$ and $7.1 \pm 9.8 \mathrm{Ma}$, respectively (Table 6), together describing an imprecise 0-20 Ma age. Using instead the higher-precision IsotopX Phoenix TIMS ${ }^{143} \mathrm{Nd} /{ }^{144} \mathrm{Nd}$ ratio of $0.512067 \pm 0.000004$ for the grt- 2 fraction, a Sm$\mathrm{Nd}$ age of $10.6 \pm 7.7 \mathrm{Ma}$ is calculated (Fig. 17b). The same age is calculated also for a 3-point isochron using this result. These $\mathrm{Sm}-\mathrm{Nd}$ results are permissive of a broadly 'Neogene' date, consistent with that inferred for UHT metamorphism of the sample.

\section{Lu mass balance}

$\mathrm{Lu}$ and $\mathrm{Hf}$ contents determined by isotope dilution (ID) for the garnet fractions were around 5.2 and $0.34 \mathrm{ppm}$, respectively (Table 5). The Hf content is similar to that determined in situ on the garnet by 


\section{MIOCENE UHT GRANULITES FROM SERAM}
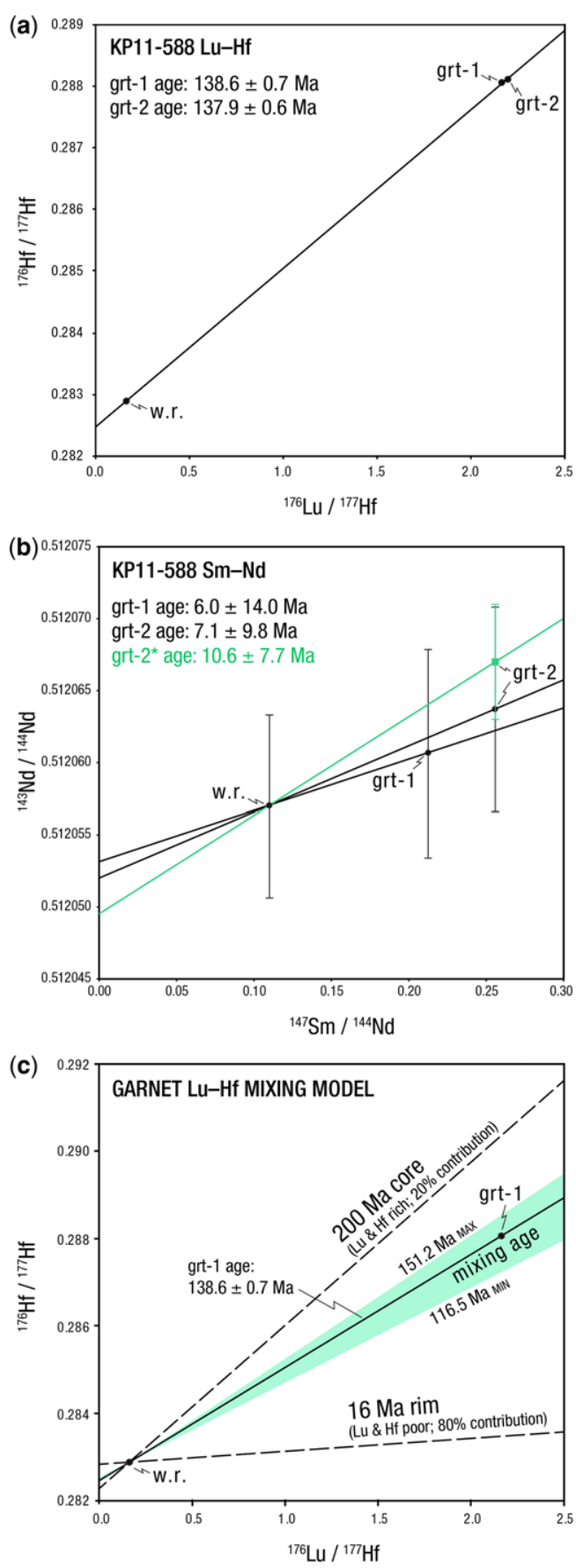

Fig. 17. Lu-Hf and Sm-Nd garnet geochronology of sample KP11-588. (a) Lu-Hf isochron diagram. Error bars are smaller than the symbols. w.r., whole rock. See Table 5 for results. (b) Sm-Nd isochron diagram. w.r., whole rock. The grt-2 fraction, ${ }^{143} \mathrm{Nd} /{ }^{144} \mathrm{Nd}$ analysed to higher precision by IsotopX Pheonix ID-TIMS (grt $2 *$ ), is plotted in green. See Table 6 for results.
LA-ICP-MS, indicating that it is unaffected by dissolution of inclusions such as zircon. However, the Lu content is substantially less than that measured by LA-ICP-MS in the garnet core, which is 10 $35 \mathrm{ppm}$ (mean c. $25 \mathrm{ppm}$ ), suggesting that the garnet separates analysed for Lu-Hf are about $20 \%$ derived from the core and $80 \%$ derived from the low-Lu rim. Since the Lu contents of the two garnet fractions analysed are only $0.5 \%$ different, they each represent very similar proportions of core and rim. Sm and $\mathrm{Nd}$ contents determined by ID were around 7 and $17 \mathrm{ppm}$, respectively. The Sm is comparable to that measured by LA-ICP-MS, but the ID Nd content is $\times 5-7$ higher, suggesting that LREE-rich inclusions have contributed substantially to the REE budget of the garnet separates, despite being uncommon.

\section{Synthesis}

Several geochronological (zircon and monazite $\mathrm{U}-\mathrm{Pb}$, garnet $\mathrm{Lu}-\mathrm{Hf}$ and $\mathrm{Sm}-\mathrm{Nd}$, and biotite ${ }^{40} \mathrm{Ar} /{ }^{39} \mathrm{Ar}$; Fig. 18), microchemical (REE analysis of zircon and garnet) and thermobarometry techniques (Ti-in-zircon; Zr-in-rutile; phase equilibria modelling) have now been applied to the residual UHT granulites of the Kobipoto Complex exposed in central Seram. To summarize these findings (new results are marked by an $*$ ):

- the protolith to the Kobipoto Complex was sourced, in part, from the Archean cratons of Western Australia and was deposited in the Late Triassic $\left(\mathrm{C}_{\mathrm{d}}\right.$ zircon $\mathrm{U}-\mathrm{Pb}$ ages between $3.4 \mathrm{Ga}$ and 216 Ma; Pownall et al. 2017a; Fig. 5);

- there were two subsequent zircon crystallization events at c. $200 \mathrm{Ma}\left(\mathrm{R}_{2}\right)$ and at $c .16 \mathrm{Ma}\left(\mathrm{R}_{\mathrm{m}}\right)$ (Pownall et al. 2014, 2017a);

- *the $c .200 \mathrm{Ma} \mathrm{R}_{2}$ zircon crystallized at $c .700^{\circ} \mathrm{C}$ (Ti-in-zircon thermometry; Fig. 15) and probably grew during a metamorphic event $(\mathrm{Th} / \mathrm{U}<1$; Fig. 14) not in equilibrium with garnet (as $R_{2}$ HREEs >× 10 garnet HREEs; Fig. 13);

- *the $c .16 \mathrm{Ma} \mathrm{R}_{\mathrm{m}}$ zircon crystallized at $c .600^{\circ} \mathrm{C}$ (Ti-in-zircon thermometry; Fig. 15) during a metamorphic event (Th/U<1; Fig. 14) in an environment where garnet was present (as $R_{m}$ HREEs garnet HREEs; Fig. 13); however,

- *zircons occurring as inclusions within garnet did not grow c. $16 \mathrm{Ma} \mathrm{R}_{\mathrm{m}}$ rims (Fig. 9b-e);

(c) Garnet Lu-Hf mixing model for KP11-588.

Combining $80 \% 16 \mathrm{Ma}$ garnet rims (1 ppm Lu; 0.030.07 ppm Hf) with $20 \% 200$ Ma garnet cores (25 ppm $\mathrm{Lu} ; 0.34 \mathrm{ppm} \mathrm{Hf}$ ) produces a mixed model age between 116.5 and 151.2 Ma (green region), which is consistent with the measured $\mathrm{Lu}-\mathrm{Hf}$ age of $138.6 \pm 0.7 \mathrm{Ma}$. For clarity, only the grt-1 2-point isochron is shown. 


\section{J. M. POWNALL ET AL.}

Table 5. Lu-Hf geochronology results, sample KP11-588

\begin{tabular}{lccccc}
\hline & $\mathrm{Lu}(\mathrm{ppm})$ & $\mathrm{Hf}(\mathrm{ppm})$ & ${ }^{176} \mathrm{Lu} /{ }^{177} \mathrm{Hf} \pm 2 \mathrm{SE}$ & ${ }^{176} \mathrm{Hf} /{ }^{177} \mathrm{Hf} \pm 2 \mathrm{SE}$ & Lu-Hf age $(\mathrm{Ma}) \pm 2 \sigma$ \\
\hline grt-1 & 5.205 & 0.341 & $2.16141 \pm 0.00648$ & $0.28806 \pm 0.00003$ & $138.6 \pm 0.7$ \\
grt-2 & 5.177 & 0.334 & $2.19218 \pm 0.00658$ & $0.28811 \pm 0.00002$ & $137.9 \pm 0.6$ \\
W.r. & 1.11 & 0.951 & $0.16500 \pm 0.00050$ & $0.28289 \pm 0.00001$ & \\
\hline
\end{tabular}

$\mathrm{Lu}$ and $\mathrm{Hf}$ abundances determined by IsoProbe MC-ICP-MS

w.r., whole rock; SE, standard error; $\sigma$, standard deviation.

- ${ }^{40} \mathrm{Ar} /{ }^{39} \mathrm{Ar}$ furnace step heating geochronology of biotite yielded an age of $16.34 \pm 0.04 \mathrm{Ma}$, which is within uncertainty of the respective $\mathrm{U}-\mathrm{Pb}$ $\left(\mathrm{R}_{\mathrm{m}}\right)$ zircon age for the same sample (Fig. 18; Pownall et al. 2014, 2017b);

- *monazite grains within the leucosome and included in garnet (re-)crystallized at c. $16 \mathrm{Ma}$ and do not record an older history (Fig. 10);

- *rutile grains in the leucosome must have crystallized under UHT conditions $\left(c .900^{\circ} \mathrm{C} \mathrm{Zr}\right.$-in-rutile $T \mathrm{~s}$ ), but rutile grains included within garnet yielded lower Zr-in-rutile temperatures of 600 $750^{\circ} \mathrm{C}$ (Fig. 16);

- *most of the garnet grew as a peritectic phase, as evidenced by the occurrence of melt inclusions (Fig. 7);

- major element zonation profiles of garnet are flat in the central region (Pownall 2015) and show evidence for resorption close to the rim (Fig. 11); however,

- *REE zonation profiles preserve evidence for distinct core and rim domains (Fig. 12);

- *the cores show large elevation in REE abundances ( $>\times 10$ that of the rims) but are relatively small, accounting for $<9$ vol\% of total garnet;

- *the garnet yielded precise Lu-Hf ages of $138.6 \pm$ 0.7 and $137.9 \pm 0.6 \mathrm{Ma}$ for the two garnet separates (Fig. 17). Based on $\mathrm{Lu}$ mass balance, the analysed garnet is about $80 \%$ derived from the rim and $20 \%$ derived from the core;

- *the garnet yielded a Sm-Nd age of 10.6 \pm 7.7 Ma, which is compromised by the large contribution of LREE-rich inclusions to the dissolved garnet Nd budget (Fig. 17).
Below is a discussion of what these results might mean for the metamorphic evolution of the Kobipoto Complex granulites.

\section{What did the zircon record?}

Since zircon may crystallize from a melt that is generated during anatexis (e.g. Schaltegger et al. 1999; Vavra et al. 1999), be modified by solid-state recrystallization (e.g. Hoskin \& Black 2000), form by subsolidus metamorphic reactions in response to $\mathrm{Zr}$ liberation (e.g. Fraser et al. 1997; Degeling et al. 2001), or may precipitate from metamorphic or metasomatic fluids across a broad range of temperatures (e.g. Rubatto \& Hermann 2003; Hay \& Dempster 2009), it is far from straightforward to assign $\mathrm{U}-\mathrm{Pb}$ zircon ages to a particular event (Harley et al. 2007). Furthermore, metamorphic-attributed $\mathrm{U}-\mathrm{Pb}$ ages are unlikely to date peak $P-T$ conditions (e.g. Roberts \& Finger 1997; Tedeschi et al. 2017) but rather an episode of zircon growth facilitated by $\mathrm{Zr}$-rich metamorphic fluids or solid-state $\mathrm{Zr}$ diffusion during metamorphic reactions. Closelymatched REE patterns between the zircon and metamorphic minerals suspected to have coexisted with the zircon under equilibrium conditions are considered by many as the best evidence for identifying 'metamorphic zircon' (e.g. Hokada \& Harley 2004; Harley et al. 2007; Rubatto \& Hermann 2007a, b). Additional evidence may come from Th/U zircon ratios, since metamorphic zircon commonly has $\mathrm{Th} / \mathrm{U}$ ratios $<0.1$ and magmatic zircon $>0.1$ (Rubatto 2002). However, there are numerous examples, particularly from metaluminous rocks, of metamorphic

Table 6. Sm-Nd geochronology results, sample KP11-588

\begin{tabular}{lcccrc}
\hline & $\mathrm{Sm}(\mathrm{ppm})$ & $\mathrm{Nd}(\mathrm{ppm})$ & ${ }^{147} \mathrm{Sm} /{ }^{144} \mathrm{Nd} \pm 2 \mathrm{SE}$ & ${ }^{143} \mathrm{Nd} /{ }^{144} \mathrm{Nd} \pm 2 \mathrm{SE}$ & $\mathrm{Sm}-\mathrm{Nd}$ age $(\mathrm{Ma}) \pm 2 \sigma$ \\
\hline grt-1 & 7.182 & 20.474 & $0.21205 \pm 0.00021$ & $0.51206 \pm 7 \mathrm{E}-6$ & $6.0 \pm 14.0$ \\
grt-2 & 6.530 & 15.442 & $0.25563 \pm 0.00026$ & $0.51206 \pm 7 \mathrm{E}-6$ & $7.1 \pm 9.8$ \\
grt-2* & & & & $0.512067 \pm 4 \mathrm{E}-6$ & $10.6 \pm 7.7$ \\
w.r. & 6.475 & 15.442 & $0.11002 \pm 0.00011$ & $0.51206 \pm 6 \mathrm{E}-6$ & \\
\hline
\end{tabular}

${ }^{* 143} \mathrm{Nd} /{ }^{144} \mathrm{Nd}$ determined to higher precision by IsotopX Pheonix TIMS. The other data are from IsoProbe MC-ICP-MS. w.r., whole rock; SE, standard error; $\sigma$, standard deviation. 


\section{MIOCENE UHT GRANULITES FROM SERAM}

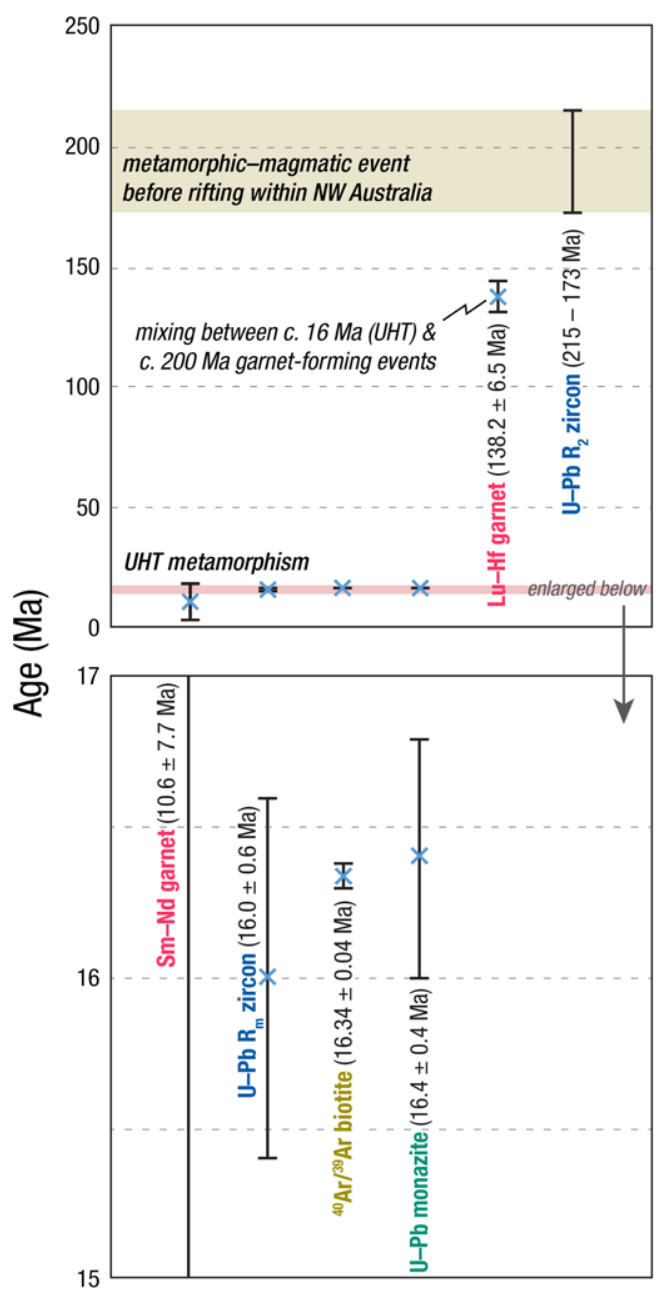

Fig. 18. Compilation of geochronology results for the Kobipoto Complex UHT granulites. U-Pb zircon ages are from Pownall et al. (2017a) and the ${ }^{40} \mathrm{Ar} /{ }^{39} \mathrm{Ar}$ biotite age is from Pownall et al. (2017b). All results are obtained for sample KP11-588, except the ${ }^{40} \mathrm{Ar} /{ }^{39} \mathrm{Ar}$ age that was obtained for KP11-619, and the age range of the $\mathrm{R}_{2}$ zircon $\mathrm{U}-\mathrm{Pb}$ dates, which are a combination of all Kobipoto Complex migmatite samples presented by Pownall et al. (2017a).

zircon with $\mathrm{Th} / \mathrm{U}$ ratios that do not match this criterion (e.g. Vavra et al. 1999; Rubatto 2017) and very low $\mathrm{Th} / \mathrm{U}$ ratios (i.e. $<0.01$ ) may instead relate to zircon formed by low- $T$ metasomatism (Harley et al. 2007).

c. 16 Ma $R_{m}$ zircon. $\mathrm{R}_{\mathrm{m}}$ zircon rims have very similar HREE abundances to garnet analysed from sample KP11-588, with garnet core and rim abundances neatly bracketing the entire range of $R_{m}$ zircon HREE profiles (Fig. 13). This provides strong evidence for the $c$. $16 \mathrm{Ma} \mathrm{R}_{\mathrm{m}}$ zircon having grown in the presence of this garnet, most probably from $\mathrm{Zr}$ liberated by consumption of the garnet rims (cf. Degeling et al. 2001; Sajeev et al. 2010). A metamorphic origin is further supported by $\mathrm{U} / \mathrm{Pb}$ ratios that are consistently $<0.1$ (Fig. 14).

As discussed by Pownall (2015), it is unlikely that the $16 \mathrm{Ma}$ zircon (and, for similar reasons, the $16 \mathrm{Ma}$ monazite) date the peak of metamorphism (cf. Yakymchuk \& Brown 2014; Kohn et al. $2015)$, but instead a point on the $P-T$ path that has passed through UHT conditions. Zircon growth can only occur if sufficient free $\mathrm{Zr}$ is available, so if $\mathrm{Zr}$-bearing minerals, such as garnet, were consumed, $\mathrm{Zr}$ would have been liberated and zircon growth enabled or promoted (cf. Degeling et al. 2001). The retrograde history of the Kobipoto Complex UHT granulites is characterized by the replacement of garnet during reaction with sillimanite to form cordierite + spinel-dominated ordered reaction microstructures and zircons located in this microtextural setting crystallized $\mathrm{R}_{\mathrm{m}}$ rims. As noted by Sajeev et al. (2010), the formation of cordierite from garnet in the presence of melt would have released $\mathrm{Zr}$ that would have promoted zircon growth (cf. Fraser et al. 2000; Degeling et al. 2001). We therefore interpret that the $c .16 \mathrm{Ma}_{\mathrm{m}}$ zircon rims were produced by post-peak metamorphic reactions that also produced the cordierite coronae and cordierite-spinel symplectites (Fig. 3e). This would have occurred during near-isothermal retrogression, after the metamorphic peak and below 6 kbar pressure - the lower- $P$ limit of garnet stability (Fig. 4). Ti-in-zircon thermometry would pinpoint the $\mathrm{R}_{\mathrm{m}}$ zircon crystallization temperature at $c .600^{\circ} \mathrm{C}$ (Fig. 15), although THERMOCALC AvePT thermometry yielded slightly hotter $\left(754 \pm 116^{\circ} \mathrm{C}\right.$ at $\left.4.0 \pm 1.0 \mathrm{kbar}\right)$ conditions for the post-peak reaction microstructures (Pownall 2015). Despite not having dated peak metamorphism, the complex's rapid exhumation and cooling history inferred from ${ }^{40} \mathrm{Ar} /{ }^{39} \mathrm{Ar}$ geochronology (Pownall et al. 2014, 2017b) would mean that $\mathrm{R}_{\mathrm{m}}$ zircon crystallization occurred very shortly afterwards.

Interestingly, zircon grains included in garnet did not grow $R_{m}$ rims (Fig. 9) and so did not record c. $16 \mathrm{Ma}$ ages. These zircons experienced the entire UHT metamorphic event without being affected by it, presumably because they were isolated from $\mathrm{Zr}^{4+}$ liberated by garnet rim breakdown after the metamorphic peak. We therefore infer that the c. $30 \%$ of grains from sample KP11-588 mounted for SHRIMP U-Pb dating that do not feature $\mathrm{R}_{\mathrm{m}}$ rims were separated from within garnet and the rest from post-peak reaction microstructures and the leucosome.

Despite not having formed under UHT conditions, the $\mathrm{R}_{\mathrm{m}}$ zircon rims have several characteristics in common with zircons interpreted to have formed 


\section{J. M. POWNALL ET AL.}

under UHT metamorphic conditions in different terranes (e.g. Santosh et al. 2007; Sajeev et al. 2010; Kusiak et al. 2013). These 'UHT zircons' are reported typically as being U-rich (CL dark) and poorly-zoned with low $\mathrm{Th} / \mathrm{U}$ ratios. Santosh et al. (2007) proposed that an increase in metamorphic temperature progressively destroys the oscillatory zoning, leaving the zircon uniformly dark in CL. Sajeev et al. (2010) attributed poorly-zoned zircon overgrowths with low $\mathrm{Th} / \mathrm{U}$ ratios and similar low CL response from Sri Lankan granulites to UHT metamorphism at c. $550 \mathrm{Ma}$. Similarly, Kusiak et al. (2013) described CL-dark low-Th, high-U UHT zircon from the Napier Complex, Antarctica. We demonstrate here the possibility that 'UHT zircon' matching the same chemistry and texture may also form at much lower temperatures after the UHT metamorphic peak.

c. $200 \mathrm{Ma} R_{2}$ zircon. $\mathrm{R}_{2}$ zircon zones have $\mathrm{HREE}$ abundances at least an order of magnitude higher than $R_{m}$ zircon rims and the garnet (Fig. 13). For this reason, it is unlikely that they grew during the most recent episode of garnet crystallization related to the UHT metamorphism. They must have instead grown during an earlier event. Ti-in-zircon temperatures of $c .700^{\circ} \mathrm{C}$ and relatively low $\mathrm{U} / \mathrm{Th}$ ratios (mostly $<0.1)$ together suggest a metamorphic origin for the zircon at around upper-amphibolite grade. As $\mathrm{R}_{2}$ zircon formed, in part, by recrystallization of the detrital cores (Pownall et al. 2017a), growth was likely in the presence of ample fluid/melt. There is also a possibility that this $\mathrm{R}_{2}$ zircon grew contemporaneously with an early episode of garnet growth, or at least during the same Late Triassic-Early Jurassic orogenic event in which garnet also formed, as discussed later.

These results further support the interpretation of an upper-amphibolite facies metamorphic event having affected the NW Australian margin in the Late Triassic-Early Jurassic (Pownall et al. 2017a). According to tectonic reconstructions by Hall (2012), this metamorphic event would shortly predate rifting of the Banda and Argo blocks from NW Australia and the subsequent opening of the Proto-Banda Sea in the Middle Jurassic.

\section{What did the monazite record?}

Monazite grains dated in situ from the leucosome and from within garnet gave ages of $16.4 \pm 0.4 \mathrm{Ma}$ (Fig. 10) - identical, within uncertainty, to the $\mathrm{R}_{\mathrm{m}}$ zircon. We therefore interpret the monazite to have similarly dated a point on the high-temperature decompression path after the peak of UHT metamorphism and in the presence of melt. As the monazite inclusion dated in this study is located close to leucosome in the margin of the garnet and also connected to a fracture network (Fig. 6d), it may have been recrystallized by circulating fluids shortly postdating the UHT event (cf. Williams et al. 2011; Kelly et al. 2012; Taylor et al. 2014). $\mathrm{R}_{2}$ zircon inclusions within garnet were evidently more resilient to any fluid-mediated resetting effect.

\section{What do the Zr-in-rutile temperatures mean?}

Rutile grains from the leucosome (Fig. 6f) recorded Zr-in-rutile temperatures (Tomkins et al. 2007) as high as $907 \pm 14^{\circ} \mathrm{C}$, whereas rutile grains included in garnet (Fig. 6e) recorded temperatures between c. $600^{\circ} \mathrm{C}$ and $750^{\circ} \mathrm{C}$ (Fig. 16). In the leucosome, it is reasonable to assume an $a \mathrm{SiO}_{2}$ of 1 and unimpeded exchange of $\mathrm{Zr}^{4+}$ and $\mathrm{Ti}^{4+}$ between rutile and $\left(R_{m}\right)$ zircon. We therefore consider this result to be a reliable piece of further evidence that the Kobipoto Complex granulites were metamorphosed under UHT conditions.

The rutile grains within garnet must have also experienced the same peak temperature but failed to record it. This is likely because the rutile and $\left(R_{2}\right)$ zircon grains included within garnet on the prograde path were shielded from each other under peak conditions and were not able to equilibrate, prohibiting free $\mathrm{Zr}^{4+} \leftrightharpoons \mathrm{Ti}^{4+}$ exchange. Failure of zircon grains within garnet to crystallize $c .16 \mathrm{Ma}\left(\mathrm{R}_{\mathrm{m}}\right)$ rims further demonstrates that $\mathrm{Zr}^{4+}$ from the leucosome did not pass into garnet. The broad spread in rutile $\mathrm{Zr}$ contents may therefore reflect the different temperatures $\left(c .600-750^{\circ} \mathrm{C}\right)$ at which rutile grains were included in prograde garnet.

\section{What do the $138 \mathrm{Ma}$ Lu-Hf garnet ages mean?}

The $138.6 \pm 0.7$ and $137.9 \pm 0.6 \mathrm{Ma} \mathrm{Lu}-\mathrm{Hf}$ garnet ages (Fig. 17a) are at first puzzling because an Early Cretaceous metamorphic or magmatic episode has never before been reported for Australianaffinity crust in east Indonesia. Previous work indicates a period of tectonic and magmatic quiescence in the NW Australian margin at this time (e.g. Audley-Charles 1988; Fraser et al. 1993; Hall 2012). A c. 143 Ma metamorphic episode has been documented in western Borneo, but not from a part of Borneo that was derived from Australia (Breitfeld et al. 2017). Given also that for the same sample (1) this $138 \mathrm{Ma} \mathrm{Lu}-\mathrm{Hf}$ garnet age does not correlate even closely with zircon or monazite crystallization events, (2) garnet HREE abundances equilibrated with those in $16 \mathrm{Ma}$ zircon (Fig. 13) and (3) the respective Sm-Nd garnet age is significantly younger $(10.6 \pm 7.7 \mathrm{Ma}$, although imprecise), we do not think that this Cretaceous Lu-Hf age can date a real metamorphic or magmatic event. We argue below that this age is the result of mixing between c. 200 Ma garnet cores with $c .16$ Ma garnet rims. 


\section{MIOCENE UHT GRANULITES FROM SERAM}

In order that ${ }^{176} \mathrm{Hf}$ produced during the $c .200 \mathrm{Ma}$ event was not lost from the garnet by diffusion during UHT metamorphism at $c$. $16 \mathrm{Ma}$, we further argue that duration of the UHT metamorphism must have been very short.

The Kobipoto Complex garnets retain evidence in their HREE zonation for two separate episodes of garnet growth (Fig. 12) despite having relatively flat major element profiles (Fig. 11). Hf and Lu concentrations are $\times 3$ and $\times 30$ higher, respectively, in garnet cores compared to the rims. On the other hand, $\mathrm{Sm}$ and $\mathrm{Nd}$ concentrations are more uniform and do not feature a sharp core-rim transition. Furthermore, the Lu-Hf garnet ages of $137.9 \pm 0.6$ and $138.6 \pm 0.7 \mathrm{Ma}$ are significantly older than their respective $10.6 \pm 7.7 \mathrm{Ma} \mathrm{Sm}-\mathrm{Nd}$ age. Although it is common for Lu-Hf ages to be slightly older than $\mathrm{Sm}-\mathrm{Nd}$ ages for the same garnet sample grown during a single metamorphic event (e.g. Anczkiewicz et al. 2007, 2012; Kylander-Clark et al. 2007; Bird et al. 2013; Smit et al. 2013; Yakymchuk et al. 2015), in this instance the discrepancy is far too large to be accounted for by any systematic offset. A component of $\mathrm{Hf}^{4+}$, but not $\mathrm{Nd}^{3+}$, must have been derived from a previous metamorphic event, requiring that (1) part of the garnet is significantly older than the UHT metamorphism, and (2) the UHT metamorphic event then remobilized major element and LREE cations (including $\mathrm{Sm}$ and $\mathrm{Nd}$ ) without significantly redistributing the highlyretentive cations (including $\mathrm{Lu}$ and $\mathrm{Hf}$ ).

These requirements are permitted by the different $\mathrm{Lu}-\mathrm{Hf}$ and $\mathrm{Sm}-\mathrm{Nd}$ closure temperatures and $\mathrm{Lu}^{3+}$ and $\mathrm{Hf}^{4+}$ diffusion behaviours in garnet. According to Smit et al. (2013), for rapid cooling rates $\left(>100^{\circ} \mathrm{C} \mathrm{Ma}^{-1}\right)$ and a garnet diffusion domain radius of $1 \mathrm{~mm}$, the closure temperature of both $\mathrm{Sm}-\mathrm{Nd}$ and $\mathrm{Lu}-\mathrm{Hf}$ systems would be approximately $>850^{\circ} \mathrm{C}$ and $>1000^{\circ} \mathrm{C}$, respectively. Furthermore, Bloch et al. (2015, p. 16) determined that $\mathrm{Hf}^{4+}$ (and $\mathrm{Lu}^{3+}$ ) are only able to fully homogenize when 'unusually long periods of metamorphism persist', or when very high temperatures (i.e. $>>900^{\circ} \mathrm{C}$ ) are attained. For instance, to fully homogenize its Hf a $1 \mathrm{~mm}$-diameter garnet may take c. $12 \mathrm{Ma}$ at $900^{\circ}$ C, but c. $250 \mathrm{Ma}$ at $800^{\circ} \mathrm{C}$ (Bloch et al. 2015, p. 16, fig. 12). The fact that HREE zoning is preserved in garnet (Fig. 13) and that UHT metamorphism did not 'reset' the Lu-Hf clock indicates that the duration of UHT metamorphism must have been short (i.e. significantly less than $12 \mathrm{Ma}$ - perhaps just a few Ma).

The metamorphic event recorded by the $\mathrm{R}_{2}$ zircon between 215 and $173 \mathrm{Ma}$ is the only known candidate for producing an older generation of garnet from which this older Hf might have been sourced. As such, we propose that the garnet cores formed during the previously-identified Late Triassic-Early
Jurassic amphibolite-facies metamorphic event. It might be expected that HREE concentrations of garnet cores and $\mathrm{R}_{2}$ zircon should be similar, if it is assumed that these two minerals grew in equilibrium. However, while not opened to complete diffusion, a slight depletion in garnet core HREE concentration may still have occurred during the UHT event. This is one possible explanation why garnet core HREE concentrations are lower than those of $\mathrm{R}_{2}$ zircon (Fig. 13). An alternative explanation is that $R_{2}$ zircon and garnet grew during different stages of the same orogenic event and/or formed in different domains and so never had similar HREE abundances.

Lu-Hf garnet mixing model. In order to test the viability of this idea, we performed a simple mixing calculation using values approximated from the LA-ICP-MS core-rim traverses (Fig. 12) of $\mathrm{Lu}_{\text {core }} /$ $\mathrm{Lu}_{\text {rim }}=25 \mathrm{ppm} / 1 \mathrm{ppm}=25$ and $\mathrm{Hf}_{\text {core }} / \mathrm{Hf}_{\text {rim }}=$ $0.34 \mathrm{ppm} / 0.05 \mathrm{ppm}=6.80$, and using the whole rock data shown in Table 5 . The core age was fixed at $200 \mathrm{Ma}$ and the rim age fixed at $16 \mathrm{Ma}$ by rotating manually the slope of the model isochrons about the whole rock ${ }^{176} \mathrm{Hf} /{ }^{177} \mathrm{Hf}$ and ${ }^{176} \mathrm{Lu} /{ }^{177} \mathrm{Hf}$ ratios. Cores and rims were then mixed in a $20_{\text {core }}: 80_{\text {rim }}$ ratio, as determined from the Lu mass balance (discussed previously). This produced a mixed-model age of 131.3 Ma. However, this model age is very sensitive to the $\mathrm{Hf}_{\text {core }} / \mathrm{Hf}_{\text {rim }}$ ratio, which cannot be determined accurately from the available LA-ICP-MS traverses. Taking lower and upper estimates for $\mathrm{Hf}_{\text {core }} / \mathrm{Hf}_{\text {rim }}$ of 4.9 (using instead $0.07 \mathrm{ppm} \mathrm{Hf}_{\text {rim }}$ ) and 11.3 (using instead $0.03 \mathrm{ppm} \mathrm{Hf}_{\text {rim }}$ ) yielded model mixing ages between 116.5 and 151.2 Ma (Fig. 17c). The actual Lu-Hf ages of $137.9 \pm 0.6$ and $138.6 \pm 0.7 \mathrm{Ma}$ fall squarely between these limits. Therefore, we demonstrate that it is entirely plausible that the c. $138 \mathrm{Ma} \mathrm{Lu-Hf}$ ages were produced by mixing between $c$. $200 \mathrm{Ma}$ cores (20\% contribution) and c. $16 \mathrm{Ma}$ rims ( $80 \%$ contribution).

Although a smaller component of the mixed age, the $c .200 \mathrm{Ma}$ cores have far higher $\mathrm{Lu}$ and $\mathrm{Hf}$ concentrations than the $c$. $16 \mathrm{Ma}$ rims (Fig. 12) and so affected the age to a greater extent. Also, since $\mathrm{Lu}^{3+}$ diffusion is around $\times 10$ faster than $\mathrm{Hf}^{4+}$ diffusion (e.g. Kohn 2009; Anczkiewicz et al. 2012; Baxter \& Scherer 2013), partial HREE retention may have lowered residual ${ }^{176} \mathrm{Lu} /{ }^{177} \mathrm{Hf}$ ratios, further skewing $\mathrm{Lu}-\mathrm{Hf}$ ages towards older values (up until the point all $\mathrm{Hf}^{4+}$ and $\mathrm{Lu}^{3+}$ are lost and the age is reset). This issue of Hf inheritance from earlier garnet growth events has been described previously as resulting in systematically older $\mathrm{Lu}-\mathrm{Hf}$ ages (Bloch \& Ganguly 2015; Raimondo et al. 2017). Counter to this, garnet resorption, which has affected the garnets of the Koibpoto Complex granulites to a large extent, may have resulted in a younging of the 
(a) Archean (b) Late Triassic - Early Jurassic (c) Early Cretaceous

$$
\text { - Late }
$$

Triassic

$3400-$

$216 \mathrm{Ma}$

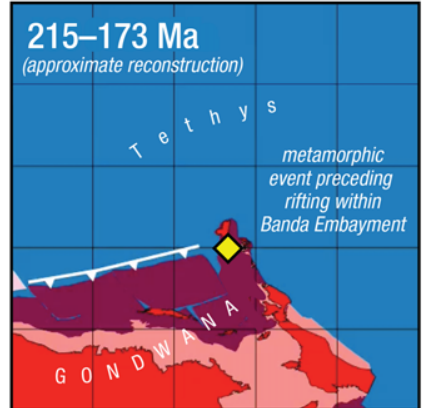

Detrital zircon

sourced from

Australian

continent

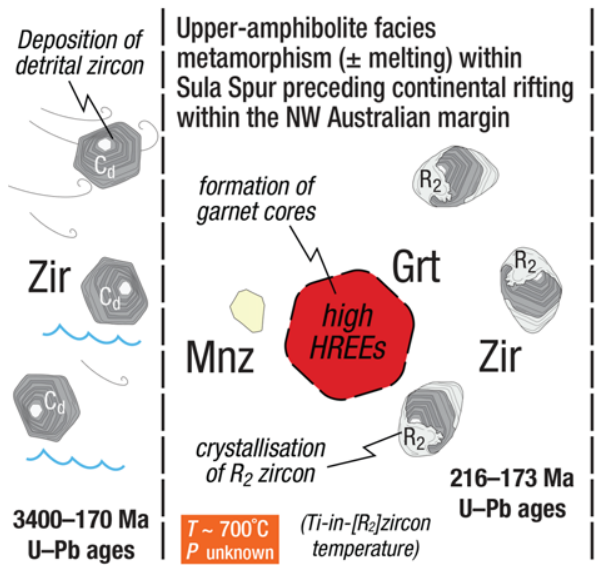

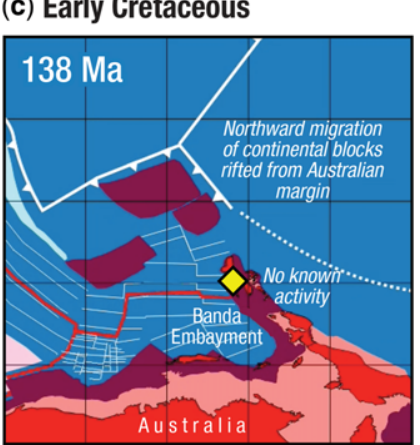

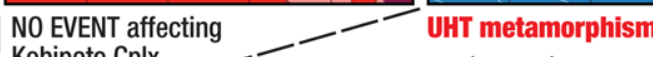

(d) Miocene

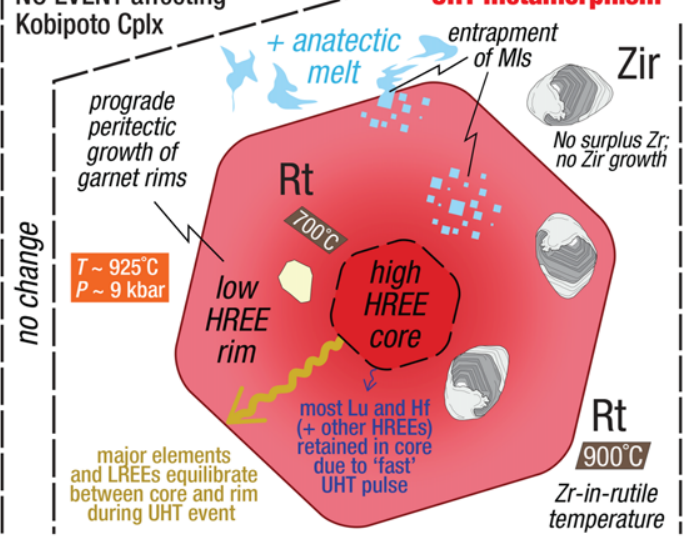

(d) Miocene
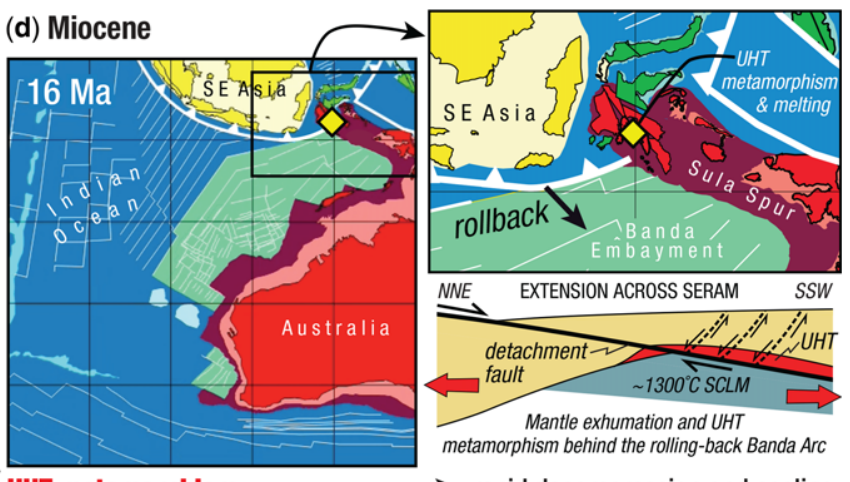

rapid decompression and cooling

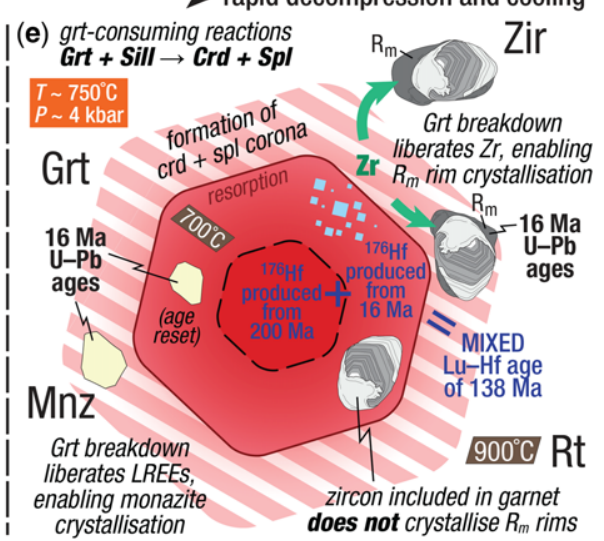

Fig. 19. Explanation of zircon, garnet, monazite and rutile histories for the Kobipoto Complex granulites linked to tectonic reconstruction of the Banda region (Hall 2012). The reconstructions (for $80-130^{\circ} \mathrm{E}, 0-50^{\circ} \mathrm{S}$ ) show oceanic crust in mint green (older than $120 \mathrm{Ma}$ ) and mid-blue (younger than $120 \mathrm{Ma}$ ), and submarine arcs and oceanic plateaus in pale blue. The yellow diamond indicates the location of central Seram. $P-T$ values (orange boxes) are from Pownall (2015) and Ti-in-zircon thermometry (Fig. 15). The cartoon minerals are not to scale. (a) Australian detrital zircon $\left(\mathrm{C}_{\mathrm{d}}\right)$ was deposited as part of the Kobipoto Complex protolith in the Late Triassic. (b) Upper amphibolite-facies metamorphic event(s) between 216 and 170 Ma grew $\mathrm{R}_{2}$ zircon and garnet cores. (c) No known event occurred at $138 \mathrm{Ma}$. (d) UHT metamorphism affected the Kobipoto Complex just prior to $16 \mathrm{Ma}$. Prograde peritectic growth of garnet rims trapped melt. Major element and LREE cations equilibrated between core and rim, but more retentive HREEs were largely retained in the core. Rutiles in the leucosome recorded $>900^{\circ} \mathrm{C} \mathrm{Zr-in-Rt} \mathrm{temperatures.} \mathrm{(e)} \mathrm{Upon} \mathrm{rapid} \mathrm{decompression} \mathrm{and} \mathrm{cooling} \mathrm{from} \mathrm{UHT} \mathrm{conditions,}$ consumption of garnet liberated $\mathrm{Zr}$ and LREEs that facilitated the growth of $c$. $16 \mathrm{Ma} \mathrm{R}_{\mathrm{m}}$ zircon and monazite, respectively. Zircon shielded in garnet did not record the UHT event. $138 \mathrm{Ma}$ garnet Lu-Hf age is the result of mixing between cores and rims. Sketch cross-section adapted from Pownall (2015). 


\section{MIOCENE UHT GRANULITES FROM SERAM}

$\mathrm{Lu}-\mathrm{Hf}$ age as $\mathrm{Lu}^{3+}$ is preferentially retained over $\mathrm{Hf}^{4+}$ in the resorbed portion of the garnet (Kelly et al. 2011).

\section{Summary}

UHT metamorphism and melting on Seram occurred just prior to $16 \mathrm{Ma}$ and an upper-amphibolite facies metamorphic event occurred during the Triassic/ Jurassic (c. $200 \mathrm{Ma}$ ), for the following reasons:

(1) the HREE abundances in garnet (a major constituent of the peak UHT metamorphic assemblage) tightly bracket those in the 16 Ma zircon, whereas $200 \mathrm{Ma}$ zircon HREE abundances are $\times 10$ higher (Fig. 13);

(2) monazite included within garnet yielded a ${ }^{206} \mathrm{~Pb} /{ }^{238} \mathrm{U}$ age of $16.4 \pm 0.4 \mathrm{Ma}$ (Fig. 10) within uncertainty of those ages from zircon (Fig. 18);

(3) $\mathrm{Th} / \mathrm{U}$ ratios for the $c .16 \mathrm{Ma} \mathrm{R}_{\mathrm{m}}$ zircon are consistently below 0.1 , consistent with a metamorphic origin (Fig. 14);

(4) garnet yielded a Sm-Nd age of 10.6 \pm 7.7 Ma, within uncertainty of $c .16$ Ma zircon;

(5) garnet Lu-Hf ages of c. $138 \mathrm{Ma}$ are explained by mixing between $c$. $200 \mathrm{Ma}$ cores with c. $16 \mathrm{Ma}$ rims (Fig. 17c);

(6) rutile present in the leucosome records Zr-in-rutile temperatures $>900^{\circ} \mathrm{C}$ (Fig. 16);

(7) multiple ${ }^{40} \mathrm{Ar} /{ }^{39} \mathrm{Ar}$ ages (Pownall et al. 2017b) also document a regionally-significant metamorphic event that affected Seram's Tehoru Formation at $16 \mathrm{Ma}$;

(8) a $17 \mathrm{Ma}{ }^{40} \mathrm{Ar} /{ }^{39} \mathrm{Ar}$ age from phlogopite in a lamprophyric dyke intruding the Kobipoto Complex lherzolite demonstrates the presence of hot mantle rocks at that time, necessary to have achieved UHT conditions (Pownall et al. 2017b);

(9) tectonic reconstructions at c. $16 \mathrm{Ma}$ indicate a marked change in the tectonic environment in the Banda region, as the Banda slab began to subduct with rollback of the subduction hinge ESE into the Banda Embayment (Fig. 19), driving regional extension (Spakman \& Hall 2010; Hall 2011, 2018).

These multiple lines of evidence add further support to the interpretation that the Seram granulites recorded Earth's youngest-known episode of UHT crustal metamorphism in response to rollback-driven mantle exhumation (Pownall et al. 2014, 2017a).

We further propose that garnet cores grew at c. $200 \mathrm{Ma}$, during the same orogenic event that caused $\mathrm{R}_{2}$ zircon crystallization. During the Miocene UHT event, prograde garnet rims overgrew these older cores. The major elements later equilibrated between the two different generations during peak conditions, erasing any zoning. Upon rapid cooling and decompression from UHT conditions, garnets cooled through the $\mathrm{Sm}-\mathrm{Nd}$ closure temperature (consistent with the $\mathrm{Sm}-\mathrm{Nd}$ age being equal to or less than the zircon and monazite $\mathrm{U}-\mathrm{Pb}$ ages), but the garnet was never hot enough for long enough to have been 'opened' to appreciable $\mathrm{Hf}^{4+}$ diffusion. Consequently, the thermal pulse that drove UHT metamorphism must have been short (Pownall et al. 2014; Pownall 2015) and failed to enable complete outward diffusion of $\mathrm{Hf}^{4+}$ accumulated in the $c .200 \mathrm{Ma}$ garnet cores. These 'fast' granulites (Harley 2016) cannot have existed above $900^{\circ} \mathrm{C}$ much longer than a few million years before being exhumed very rapidly, as supported also by the identical-within-uncertainty biotite ${ }^{40} \mathrm{Ar} /{ }^{39} \mathrm{Ar}$ (Pownall et al. 2017b), zircon $\mathrm{U}-\mathrm{Pb}$ and monazite $\mathrm{U}-\mathrm{Pb}$ ages (Fig. 18).

\section{Conclusions}

\section{Metamorphic evolution of the Kobipoto Complex UHT granulites}

(1) The pelitic protolith to the Kobipoto Complex granulites was deposited by $216 \mathrm{Ma}$. Detrital zircons $\left(\mathrm{C}_{\mathrm{d}}\right)$ as old as $3.4 \mathrm{Ga}$ confirm this material was derived, in part, from the western Australian cratons (Fig. 19a).

(2) The protolith to the Kobipoto Complex was metamorphosed in the upper-amphibolite facies ( \pm partial melting) between 215 and $173 \mathrm{Ma}$ as recorded by $\mathrm{R}_{2}$ zircon rims that partially recrystallized older $\mathrm{C}_{\mathrm{d}}$ cores (evidenced

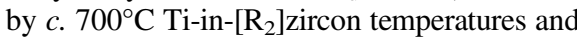
$\mathrm{Th} / \mathrm{U}<0.1)$. Small garnets with high HREE contents also likely grew during this Late Jurassic-Early Cretaceous event, in order to account for elevated ${ }^{176} \mathrm{Hf}$ contents that cannot be explained by a single garnet growth event at c. $16 \mathrm{Ma}$. It is possible that more than one metamorphic-magmatic episode occurred between 215 and 173 Ma which shortly predated the rifting of adjacent continental blocks from the NW Australian margin (Fig. 19b).

(3) Prograde metamorphism preceding the UHT peak was not recorded by the investigated geochronometers, but must have occurred between $23 \mathrm{Ma}$ (the initial Australia-SE Asia collision age; Hall 2011) and $16 \mathrm{Ma}$ (growth of retrograde $\mathrm{R}_{\mathrm{m}}$ zircon and monazite). Garnet growth, principally as a peritectic product (evidenced by melt inclusions) engulfed many $\mathrm{C}_{\mathrm{d}}+$ $\mathrm{R}_{2}$ zircon grains and some rutile and monazite grains (Fig. 19d). The zircons, after their inclusion in garnet, did not crystallize new rims. Rutile grains, after their inclusion, did not adjust 


\section{J. M. POWNALL ET AL.}

their $\mathrm{Zr}$ contents, recording collectively a spread of different $\mathrm{Zr}$-in-rutile temperatures $\left(600-750^{\circ} \mathrm{C}\right)$ along the prograde path.

(4) Hot leucosome must have been present at the peak of UHT metamorphism $\left(925^{\circ} \mathrm{C}\right.$ and 9 kbar; Pownall 2015). Rutile grains within the leucosome, adjacent to garnet, recorded $\mathrm{Zr}$-in-rutile temperatures of $c .900^{\circ} \mathrm{C}$ through exchange of $\mathrm{Zr}^{4+}$ and $\mathrm{Ti}^{4+}$ with zircon grains present also in the leucosome (Fig. 19d). At this time, garnet comprised a modelled $30 \mathrm{vol} \%$ of the rock (Pownall 2015). As the garnets no longer preserve major element or LREE core-rim zoning, in contrast to the more retentive HREEs, it is likely that these less retentive cations were homogenized under peak conditions. Diffusion of HREEs from core to rim may have occurred to a small extent, since $R_{2}$ zircon which grew contemporaneously with the garnet cores at c. 200 Ma have higher HREE abundances.

(5) During the granulites' post-peak evolution, garnet reacted with sillimanite to form the cordierite and spinel-rich coronae. At c. $16 \mathrm{Ma}$, as the rock was exhumed above $c .20 \mathrm{~km}$ depth (c. $6 \mathrm{kbar}$ ), garnet no longer remained part of the equilibrium assemblage. $\mathrm{Zr}^{4+}$ liberated by metamorphic reactions consuming the outermost garnet rims drove crystallization of $c .16 \mathrm{Ma} \mathrm{R}_{\mathrm{m}}$ rims on zircon grains in the leucosome and on zircons now located in cordierite + spinel post-peak reaction microstructures (Fig. 19e). Ti-in-[ $\left[\mathrm{R}_{\mathrm{m}}\right]$ zircon temperatures of just $600^{\circ} \mathrm{C}$ attest to the late crystallization of zircon in the UHT granulites' retrograde history.

(6) The $138.6 \pm 0.7$ and $137.9 \pm 0.6 \mathrm{Ma}$ garnet Lu-Hf ages do not correlate to any known geological event in the Banda region (Fig. 19c). We interpret these ages to be the product of mixing between $c .200 \mathrm{Ma}$ garnet cores (c. $20 \%$ contribution) and c. 16 Ma garnet rims (c. $80 \%$ contribution) (Figs $17 \mathrm{c} \& 19 \mathrm{e})$. The garnet $\mathrm{Sm}-\mathrm{Nd}$ age of $10.6 \pm 7.7 \mathrm{Ma}$ is imprecise, but most probably records initial cooling from the UHT metamorphic peak at $c .16 \mathrm{Ma}$. Unlike Hf, there is no evidence that Nd produced within $c$. $200 \mathrm{Ma}$ garnet cores was retained in garnet during Miocene UHT metamorphism. In order that the Lu-Hf 'clock' was not reset by the UHT metamorphism, the granulites cannot have resided under UHT conditions for longer than a few million years.

\section{Broader implications}

(1) Zircon grains in shielded microtextural sites (in this instance as inclusions within garnet) may be subjected to an entire UHT metamorphic cycle without crystallizing new rims and therefore without recording the UHT event.

(2) Short-lived UHT metamorphic events are sometimes unable to reset the $\mathrm{Lu}-\mathrm{Hf}$ system in garnet. In such instances, Hf retention from a previous metamorphic event may lead to a mixed $\mathrm{Lu}-\mathrm{Hf}$ age even for garnets that no longer preserve major element zonation.

(3) Rather than having formed within a large, long-lived, hot collisional orogen - the most common explanation for UHT rocks discovered in Proterozoic terranes - these Indonesian Miocene granulites record a history of shortlived UHT metamorphism and subsequent rapid exhumation.

Acknowledgements Many thanks to Yasinto Priastomo, Ramadhan Adhitama, and Adianto Trihatmojo (Institut Teknologi Bandung) for assistance during the fieldwork that made this study possible. Thanks also to Juliane Hennig for assistance with garnet dating, James Tolley for assistance with the RSES LA-ICP-MS system, Melanie Sieber for helping to acquire the in-situ CL images of zircon grains and Antonio Acosta-Vigil for encouraging me to search for melt inclusions. This paper benefitted greatly from insightful reviews by Chris Yakymchuk, the editorship of Pierre Lanari and discussions with Anna Bird and Steph Walker.

Funding This research was funded by the SE Asia Research Group (Royal Holloway, University of London) and Australian Research Council (ARC) DECRA fellowship DE160100128 awarded to JMP.

\section{References}

Aleinikoff, J.N., Schenck, W.S., Plank, M.O., Srogi, L., Fanning, C.M., Kamo, S.L. \& Bosbyshell, H. 2006. Deciphering igneous and metamorphic events in highgrade rocks of the Wilmington Complex, Delaware: Morphology, cathodoluminescence and backscattered electron zoning, and SHRIMP U-Pb geochronology of zircon and monazite. GSA Bulletin, 118, 39-64, https://doi.org/10.1130/B25659.1

Anczkiewicz, R. \& ThiRlwall, M.F. 2003. Improving precision of Sm-Nd garnet dating by $\mathrm{H}_{2} \mathrm{SO}_{4}$ leaching: a simple solution to the phosphate inclusion problem. In: Vance, D., Müller, W. \& Villa, I.M. (eds) Geochronology: Linking the Isotope Record with Petrology and Textures. Geological Society, London, Special Publications, 220, 83-91, https://doi.org/10.1144/ GSL.SP.2003.220.01.05

AnCZKIEwicz, R., MAZur, S. ET AL. 2007. Lu-Hf geochronology and trace element distribution in garnet: implications for uplift and exhumation of ultra-high pressure granulites in the Sudetes, SW Poland. Lithos, 95, 363-380.

Anczkiewicz, R., Thirlwall, M.F., Alard, O., Rogers, N.W. \& Clark, C. 2012. Diffusional homogenization of light REE in garnet from the Day Nui Con Voi 


\section{MIOCENE UHT GRANULITES FROM SERAM}

Massif in N-Vietnam: Implications for $\mathrm{Sm}-\mathrm{Nd}$ geochronology and timing of metamorphism in the Red River shear zone. Chemical Geology, 318-319, 16-30.

Audley-Charles, M.G. 1988. Evolution of the southern margin of Tethys (North Australian region) from early Permian to late Cretaceous. In: AudLeY-Charles, M.G. \& Hallam, A. (eds) Gondwana and Tethys. Geological Society, London, Special Publications, 37, 79-100, https://doi.org/10.1144/GSL.SP.1988.037.01.07

BAXter, E.F. \& Scherer, E.E. 2013. Garnet geochronology: timekeeper of tectonometamorphic processes. Elements, 9, 433-438.

Bird, A.F., Thirlwall, M.F., Strachan, R.A. \& Manning, C.J. 2013. Lu-Hf and Sm-Nd dating of metamorphic garnet: evidence for multiple accretion events during the Caledonian orogeny in Scotland. Journal of the Geological Society, London, 170, 301-317, https:// doi.org/10.1144/jgs2012-083

Bloch, E. \& Ganguly, J. 2015. ${ }^{176} \mathrm{Lu}-{ }^{176} \mathrm{Hf}$ geochronology of garnet II: numerical simulations of the development of garnet-whole-rock ${ }^{176} \mathrm{Lu}-{ }^{176} \mathrm{Hf}$ isochrons and a new method for constraining the thermal history of metamorphic rocks. Contributions to Mineralogy and Petrology, 169, 14, https://doi.org/10.1007/ s00410-015-1115-X

Bloch, E., Ganguly, J., Hervig, R. \& Cheng, W. 2015. ${ }^{176} \mathrm{Lu}-{ }^{176} \mathrm{Hf}$ geochronology of garnet I: experimental determination of the diffusion kinetics of $\mathrm{Lu}^{3+}$ and $\mathrm{Hf}^{4+}$ in garnet, closure temperatures and geochronological implications. Contributions to Mineralogy and Petrology, 169, 12, https://doi.org/10.1007/s00410015-1109-8

Bowin, C., Purdy, G.M., Johnston, C., Shor, G., Lawyer, L., Hartono, H. \& JezeK, P. 1980. Arc-continent collision in the Banda Sea region. AAPG Bulletin, 64 , 868-915.

Breitfeld, H.T., Hall, R., Galin, T., Forster, M.A. \& BouDagher-Fadel, M.K. 2017. A Triassic to Cretaceous Sundaland-Pacific subduction margin in West Sarawak, Borneo. Tectonophysics, 694, 35-56.

Brown, M. 2006. Duality of thermal regimes is the distinctive characteristic of plate tectonics since the Neoarchean. Geology, 34, 961-964.

Brown, M. 2014. The contribution of metamorphic petrology to understanding lithosphere evolution and geodynamics. Geoscience Frontiers, 5, 553-569.

Cesare, B., Acosta-Vigil, A., Bartoli, O. \& Ferrero, S. 2015. What can we learn from melt inclusions in migmatites and granulites? Lithos, 239, 186-216.

Charlton, T.R., Kaye, S.J., Samodra, H. \& Sardjono, 1991. Geology of the Kai Islands: implications for the evolution of the Aru Trough and Weber Basin, Banda Arc, Indonesia. Marine and Petroleum Geology, 8 , 62-69, https://doi.org/10.1016/0264-8172(91)90045-3

Degeling, H., EgGins, S. \& Ellis, D.J. 2001. Zr budgets for metamorphic reactions, and the formation of zircon from garnet breakdown. Mineralogical Magazine, $\mathbf{6 5}$, 749-758.

FERry, J.M. \& Watson, E.B. 2007. New thermodynamic models and revised calibrations for the Ti-in-zircon and Zr-in-rutile thermometers. Contributions to Mineralogy and Petrology, 154, 429-437, https://doi.org/ 10.1007/s00410-007-0201-0
FrASER, G., Ellis, D. \& EgGins, S. 1997. Zirconium abundance in granulite-facies minerals, with implications for zircon geochronology in high-grade rocks. Geology, 25, 607-610, https://doi.org/10.1130/0091-7613 (1997)025<0607:ZAIGFM>2.3.CO;2

Fraser, G., McDougall, I., Ellis, D.J. \& Williams, I.S. 2000. Timing and rate of isothermal decompression in Pan-African granulites from Rundvågshetta. East Antarctica, Journal of Metamorphic Geology, 18, 441-454.

Fraser, T.H., Bon, J. \& SAmuel, L. 1993. A new dynamic Mesozoic stratigraphy for the West Irian microcontinent Indonesia and its implications. In: $22^{\text {nd }}$ Annual Convention \& Exhibition, Indonesian Petroleum Association, Jakarta, Indonesia, 707-761.

Gafoer, S., Suwitodirdjo, K. \& Suharsono, 1993. Geological map of the Bula and Watubela sheet, Maluku, 1:250 000, Geological Research and Development Centre, Bandung, Indonesia.

GermeraAd, J.H. 1946. Geology of central Seran. In: RutTEN, L. \& Hotz, W. (eds) Geological, Petrographical, and Palaeontological Results of Explorations, Carried Out From September 1917 Till June 1919 in the Island of Ceram. De Bussy, Amsterdam, 135.

HALL, R. 2011. Australia-SE Asia collision: plate tectonics and crustal flow. In: Hall, R., CotTAM, M.A. \& WiLson, M.E.J. (eds) The SE Asian Gateway: History and Tectonics of the Australia-Asia Collision. Geological Society, London, Special Publications, 355, 75-109, https://doi.org/10.1144/SP355.5

HaLl, R. 2012. Late Jurassic-Cenozoic reconstructions of the Indonesian region and the Indian Ocean. Tectonophysics, 570-571, 1-41, https://doi.org/10.1016/j. tecto.2012.04.021

Hall, R. 2017. Southeast Asia: new views of the geology of the Malay Archipelago. Annual Review of Earth and Planetary Sciences, 45, 331-358.

HaLl, R. 2018. The subduction initiation stage of the Wilson Cycle. In: Wilson, R.W., Houseman, G.A., McCaffrey, K.J.W., Doré, A.G. \& Buiter, S.J.H. (eds) Fifty Years of the Wilson Cycle Concept in Plate Tectonics. Geological Society, London, Special Publications, 470, https://doi.org/10.1144/SP470.3

Hall, R., Patria, A., Adhitama, R., Pownall, J.M. \& White, L.T. 2017. Seram, the Seram Trough, the Aru Trough, the Tanimbar Trough and the Weber Deep: a new look at major structures in the eastern Banda Arc. In: 41st Annual Convention \& Exhibition, 17-19 May, Indonesian Petroleum Association, Jakarta, Indonesia, IPA17-91-G.

Hamilton, W. 1979. Tectonics of the Indonesian Region. US Geological Survey Professional Paper 1078.

HaRLey, S.L. 2008. Refining the $P-T$ records of UHT crustal metamorphism. Journal of Metamorphic Geology, 26, 125-154.

HaRLey, S.L. 2016. A matter of time: the importance of the duration of UHT metamorphism. Journal of Mineralogical and Petrological Sciences, 111, 50-72.

Harley, S.L., Kelly, N.M. \& Möller, A. 2007. Zircon behaviour and the thermal histories of mountain chains. Elements, 3, 25-30.

Hay, D.C. \& Dempster, T.J. 2009. Zircon behaviour during low-temperature metamorphism. Journal of Petrology, 50, 571-589, https://doi.org/10.1093/ petrology/egp011 


\section{J. M. POWNALL ET AL.}

Hensen, B.J. \& Green, D.H. 1971. Experimental study of the stability of cordierite and garnet in pelitic compositions at high pressures and temperatures: I. Compositions with excess alumino-silicate. Contributions to Mineralogy and Petrology, 33, 309-330.

Hinschberger, F., Malod, J.-A., Réhault, J.-P., Dyment, J., Honthaas, C., Villeneuve, M. \& Burhanuddin, S. 2000. Origine et evolution du basin Nord-Banda (Indonésie): apport des données magnétiques. Comptes Rendus de l'Académie des Sciences - Series IIA Earth and Planetary Science, 331, 507-514.

Hinschberger, F., Malod, J.-A., Dyment, J., HonthaAs, C., RéHault, J.-P. \& Burhanuddin, S. 2001. Magnetic lineations constraints for the back-arc opening of the Late Neogene South Banda Basin (eastern Indonesia). Tectonophysics, 333, 47-59.

HoKadA, T. \& Harley, S.L. 2004. Zircon growth in UHT leucosome: constraints from zircon-garnet rare earth element (REE) relations in Napier Complex, East Antarctica. Journal of Mineralogical and Petrological Sciences, 99, 180-190.

HonthaAs, C., Villeneuve, M. et al. 1997. L'île de Kur: géologie du flanc oriental du bassin de Weber (Indonésie orientale). Comptes Rendus de l'Académie des Sciences - Series IIA - Earth and Planetary Science, 325, 883-890.

Honthaas, C., Maury, R.C., Priadi, B., Bellon, H. \& CotTEN, J. 1999. The Plio-Quaternary Ambon arc, Eastern Indonesia. Tectonophysics, 301, 261-281, https://doi. org/10.1016/S0040-1951(98)00227-3

Hoskin, P.W.O. \& BLACK, L.P. 2000. Metamorphic zircon formation by solid-state recrystallization of protolith igneous zircon. Journal of Metamorphic Geology, 18, 423-439, https://doi.org/10.1046/j.1525-1314.2000. 00266.x

Kelly, E.D., Carlson, W.D. \& Connelly, J.N. 2011. Implications of garnet resorption for the $\mathrm{Lu}-\mathrm{Hf}$ garnet geochronometer: an example from the contact aureole of the Makhavinekh Lake Pluton, Labrador. Journal of Metamorphic Petrology, 29, 901-916.

Kelly, N.M., Harley, S.L. \& Möller, A. 2012. Complexity in the behavior and recrystallization of monazite during high-T metamorphism and fluid infiltration. Chemical Geology, 322-323, 192-208.

Kelsey, D.E. 2008. On ultrahigh-temperature metamorphism. Gondwana Research, 13, 1-29.

Kelsey, D.E. \& HAND, M. 2015. On ultrahigh temperature crustal metamorphism: Phase equilibria, trace element thermometry, bulk composition, heat sources, timescales and tectonic settings. Geoscience Frontiers, 6, 311-356.

KLOMPÉ, T.H.F. 1954. The structural importance of the Sula Spur (Indonesia). Indonesian Journal of Natural Sciences, 110, 21-40.

KoHN, M.J. 2009. Models of garnet differential geochronology. Geochimica et Cosmochimica Acta, 73, 170-182.

Kohn, M.J., Corrie, S.L. \& MARKLEY, C. 2015. The fall and rise of metamorphic zircon. American Mineralogist, 100, 897-908.

KRETZ, R. 1983. Symbols for rock-forming minerals. American Mineralogist, 68, 277-279.

Kusiak, M.A., Whitehouse, M.J., Wilde, S.A., DunKley, D.J., Menneken, M., Nemchin, A.A. \& Clark, C. 2013. Changes in zircon chemistry during Archean
UHT metamorphism in the Napier Complex, Antarctica. American Journal of Science, 313, 933-967, https://doi.org/10.2475/09.2013.05

Kylander-Clark, A.R.C., Hacker, B.R., Johnson, C.M., Beard, B.L., Mahlen, N.J. \& LAPEN, T.J. 2007. Coupled Lu-Hf and Sm-Nd geochronology constrains prograde and exhumation histories of high- and ultrahigh-pressure eclogites from western Norway. Chemical Geology, 242, 137-154.

Linthout, K., Helmers, H., Sopaheluwakan, J. \& Nila, E.S. 1989. Metamorphic complexes in Buru and Seram, Northern Banda Arc. Netherlands Journal of Sea Research, 24, 345-356, https://doi.org/10.1016/ 0077-7579(89)90160-9

Linthout, K., Helmers, H., Wijbrans, J.R. \& Van Wees, J.D.A.M. 1996. ${ }^{40} \mathrm{Ar} /{ }^{39} \mathrm{Ar}$ constraints on obduction of the Seram ultramafic complex: consequences for the evolution of the southern Banda Sea. Geological Society, London, Special Publications, 106, 455-464, https://doi.org/10.1144/GSL.SP.1996.106.01.28

LudwIG, K.R. 2003. Isoplot 3.0: A geochronological Toolkit for Microsoft Excel. Berkeley Geochronological Centre, Special Publications, 4, Berkeley, CA.

LudwIG, K.R. 2009. SQUID 2: A User's Manual. Berkeley Geochronological Centre, Special Publications, 5, Berkeley, CA.

LugmaiR, G.W. \& MARTI, K. 1978. Lunar initial ${ }^{143} \mathrm{Nd} /{ }^{144} \mathrm{Nd}$ : differential evolution of the lunar crust and mantle. Earth and Planetary Science Letters, 39, 349-357.

McDonough, W.F. \& Sun, S.-S. 1995. The composition of the Earth. Chemical Geology, 120, 223-253.

Müller, W., Shelley, M., Miller, P. \& Broude, S. 2009. Initial performance metrics of a new custom-designed ArF excimer LA-ICPMS system coupled to a twovolume laser-ablation cell. Journal of Analytical Atomic Spectrometry, 24, 209-214.

Paton, C., Hellstrom, J., Paul, B., Woodhead, J. \& Hergt, J. 2011. Iolite: Freeware for the visualisation and processing of mass spectrometric data. Journal of Analytical Atomic Spectrometry, 26, 2508-2518.

Powell, R. \& Holland, T.J.B. 1988. An internally consistent dataset with uncertainties and correlations: 3 . Applications to geobarometry, worked examples and a computer program. Journal of Metamorphic Geology, 6, 173-204.

Pownall, J.M. 2015. UHT metamorphism on Seram, eastern Indonesia: reaction microstructures and $P-T$ evolution of spinel-bearing garnet-sillimanite granulites from the Kobipoto Complex. Journal of Metamorphic Geology, 33, 909-935, https://doi.org/10.1111/jmg. 12153

Pownall, J.M. \& Hall, R. 2014. Neogene extension on Seram: a new tectonic model for the northern Banda Arc. In: 38th Annual Convention \& Exhibition, 21-23 May, Indonesian Petroleum Association, Jakarta, Indonesia, IPA14-G-305.

Pownall, J.M., Hall, R. \& Watkinson, I.M. 2013. Extreme extension across Seram and Ambon, eastern Indonesia: evidence for Banda slab rollback. Solid Earth, 4, 277-314, https://doi.org/10.5194/se-4-277-2013

Pownall, J.M., Hall, R., Armstrong, R.A. \& Forster, M.A. 2014. Earth's youngest known ultrahightemperature granulites discovered on Seram, eastern 


\section{MIOCENE UHT GRANULITES FROM SERAM}

Indonesia. Geology, 42, 279-282, https://doi.org/10. 1130/G35230.1

Pownall, J.M., Hall, R. \& Lister, G.S. 2016. Rolling open Earth's deepest forearc basin. Geology, 44, 947-950, https://doi.org/10.1130/G38051.1

Pownall, J.M., Hall, R. \& Armstrong, R.A. 2017a. Hot lherzolite exhumation, UHT migmatite formation, and acid volcanism driven by Miocene rollback of the Banda Arc, eastern Indonesia. Gondwana Research, 51, 92-117, https://doi.org/10.1016/j.gr.2017.07.003

Pownall, J.M., Forster, M.A., Hall, R. \& Watkinson, I.M. 2017b. Tectonometamorphic evolution of Seram and Ambon, eastern Indonesia: insights from ${ }^{40} \mathrm{Ar} /{ }^{39} \mathrm{Ar}$ geochronology. Gondwana Research, 44, 35-53, https://doi.org/10.1016/j.gr.2016.10.018

Priem, H.N.A., ANDriessen, P.A.M., BoelriJK, N.A.I.M., Hebeda, E.H., Hutchinson, C.S., Verdurmen, E.A.T. \& Versschure, R.H. 1978. Isotopic evidence for a middle to late Pliocene age of the cordierite granite on Ambon, Indonesia. Geologie en Mijnbouw, 57, 441-443.

Raimondo, T., Payne, J., Hand, M., Clark, C. \& AnczkiewICZ, R. 2017. Large discrepancies between garnet Lu-Hf and Sm-Nd isochron ages: the problem of inherited Hf. Geophysical Research Abstracts, 19, EGU2017-2152.

RoberTs, M.P. \& Finger, F. 1997. Do U-Pb zircon ages from granulites reflect peak metamorphic conditions? Geology, 25, 319-322, https://doi.org/10.1130/ 0091-7613(1997)025<0319:DUPZAF>2.3.CO;2

RuBAtTo, D. 2002. Zircon trace element geochemistry: partitioning with garnet and the link between $\mathrm{U}-\mathrm{Pb}$ ages and metamorphism. Chemical Geology, 184, 123-138, https://doi.org/10.1016/S0009-2541(01) 00355-2

Rubatto, D. 2017. Zircon: the metamorphic mineral. Reviews in Mineralogy and Geochemistry, 83, 261-295.

Rubatto, D. \& Hermann, J. 2003. Zircon formation during fluid circulation in eclogites (Monviso, Western Alps): implications for $\mathrm{Zr}$ and $\mathrm{Hf}$ budget in subduction zones. Geochimica et Cosmochimica Acta, 67, 2173-2187, https://doi.org/10.1016/S0016-7037(02)01321-2

Rubatto, D. \& Hermann, J. 2007a. Experimental zircon/ melt and zircon/garnet trace element partitioning and implications for the geochemistry of crustal rocks. Chemical Geology, 241, 38-61.

Rubatto, D. \& Hermann, J. 2007b. Zircon behaviour in deeply subducted rocks. Elements, 3, 31-35.

Ryan, W.B.F., CARbotte, S.M. ET AL. 2009. Global multiresolution topography synthesis. Geochemistry, Geophysics, Geosystems, $\mathbf{1 0 .}$

Sajeev, K., Williams, I.S. \& Osanai, Y. 2010. Sensitive high-resolution ion microprobe $\mathrm{U}-\mathrm{Pb}$ dating of prograde and retrograde ultrahigh-temperature metamorphism as exemplified by Sri Lankan granulites. Geology, 38, 971-974.

Santosh, M., Wilde, S.A. \& Li, J.H. 2007. Timing of Paleoproterozoic ultrahigh-temperature metamorphism in the North China Craton: Evidence from SHRIMP U$\mathrm{Pb}$ zircon geochronology. Precambrian Research, 159, 178-196.

SAwyer, E.W. 2008. Atlas of Migmatites. The Canadian Mineralogist Special Publication, 9. Ottawa, Canada.
Schaltegger, U., Fanning, C.M., Günther, D., Maurin, J.C., Schulmann, K. \& Gebauer, D. 1999. Growth, annealing and recrystallization of zircon and preservation of monazite in high-grade metamorphism: conventional and in-situ $\mathrm{U}-\mathrm{Pb}$ isotope, cathodoluminescence and microchemical evidence. Contributions to Mineralogy and Petrology, 134, 186-201, https://doi.org/10. $1007 /$ s004100050478

Scherer, E.E., Cameron, K.L. \& Blichert-Toft, J. 2000. Lu-Hf garnet geochronology: closure temperature relative to the $\mathrm{Sm}-\mathrm{Nd}$ system and the effects of trace mineral inclusions. Geochimica et Cosmochimica Acta, 64, 3413-3432, https://doi.org/10.1016/ S0016-7037(00)00440-3

Smit, M.A., Scherer, E.E. \& MEZgER, K. 2013. Lu-Hf and Sm-Nd garnet geochronology: chronometric closure and implications for dating petrological processes. Earth and Planetary Science Letters, 381, 222-233.

Spakman, W. \& Hall, R. 2010. Surface deformation and slab-mantle interaction during Banda arc subduction rollback. Nature Geoscience, 3, 562-566, https://doi. org/10.1038/ngeo917

StaceY, J.S. \& KRAMERS, J.D. 1975. Approximation of terrestrial lead isotope evolution by a two stage model Earth and Planetary Science Letters, 127, 30-45.

STEIGER, R.H. \& JÄGER, E. 1977. Subcommission on geochronology: convention on the use of decay constants in geo- and cosmoschronology. Earth and Planetary Science Letters, 36, 359-362.

Taylor, R.J.M., Clark, C., Fitzsimons, I.C.W., Santosh, M., Hand, M., Evans, N. \& McDonald, B. 2014. Postpeak, fluid-mediated modification of granulite facies zircon and monazite in the Trivandrum Block, southern India. Contributions to Mineralogy and Petrology, 168, 1044.

Tedeschi, M., Lanari, P. et al. 2017. Reconstruction of multiple P-T-t stages from retrogressed mafic rocks: Subduction versus collision in the Southern Brasília orogeny (SE Brazil). Lithos, 294-295, 283-303.

TJokrosapoetro, S. \& Budhitrisna, T. 1982. Geology and tectonics of the northern Banda Arc. Bulletin of the Indonesian Geological Research and Development Centre, 6, 1-17.

Tuokrosapoetro, S., Achdan, A., Suwitodirdjo, K., RusManA, E. \& Abidin, H.Z. 1993a. Geological Map of the Masohi Quadrangle, Maluku, 1:250 000. Geological Research and Development Centre, Bandung, Indonesia.

Tuokrosapoetro, S., Rusmana, E. \& Achdan, A. $1993 b$. Geological Map of the Ambon Sheet, Maluku, 1:250 000. Geological Research and Development Centre, Bandung, Indonesia.

Tomkins, H.S., Powell, R. \& Ellis, D.J. 2007. The pressure dependence of the zirconium-in-rutile thermometer. Journal of Metamorphic Geology, 25, 703-713.

VALK, W. 1945. Contributions to the geology of West Seran. In: RutTen, L. \& Hotz, W. (eds) Geological, Petrographical, and Palaeontological Results of Explorations, Carried Out From September 1917 Till June 1919 in the Island of Ceram. De Bussy, Amsterdam, 104.

VAN DER SLuIS, J.P. 1950. Geology of East Seran. In: RutTEN, L. \& Hotz, W. (eds) Geological, Petrographical, and Palaeontological Results of Explorations, Carried 


\section{J. M. POWNALL ET AL.}

Out From September 1917 Till June 1919 in the Island of Ceram. De Bussy, Amsterdam, 67.

Vavra, G., Schmid, R. \& Gebauer, D. 1999. Internal morphology, habit and $\mathrm{U}-\mathrm{Th}-\mathrm{Pb}$ microanalysis of amphibolite-to-granulite facies zircons: geochronology of the Ivrea Zone (Southern Alps). Contributions to Mineralogy and Petrology, 134, 380-404, https://doi. org/10.1007/s004100050492

Watson, E.B., Wark, D.A. \& Thomas, J.B. 2006. Crystallization thermometers for zircon and rutile. Contributions to Mineralogy and Petrology, 151, 413-433, https://doi.org/10.1007/s00410-006-0068-5

Williams, M.L., Jercinovic, M.J., Harlov, D.E., Budzyń, B. \& Hetherington, C.J. 2011. Resetting monazite ages during fluid-related alteration. Chemical Geology, 283, 218-225.

YAKYмchuк, C. \& Brown, M. 2014. Behaviour of zircon and monazite during crustal melting. Journal of the Geological Society, London, 171, 465-479, https:// doi.org/10.1144/jgs2013-115

YAKYmchuK, C., Brown, M. ET AL. 2015. Decoding polyphase migmatites using geochronology and phase equilibria modelling. Journal of Metamorphic Geology, 33, 203-230.

Yakymchuk, C., Clark, C. \& White, R.W. 2017. Phase relations, reaction sequences and petrochronology. Reviews in Mineralogy and Geochemistry, 83, $13-53$. 